\title{
Mineral Resources of the Eastern Pioneer Mountains, Beaverhead County, Montana
}

\section{U.S. GEOLOGICAL SURVEY BULLETIN 1766}

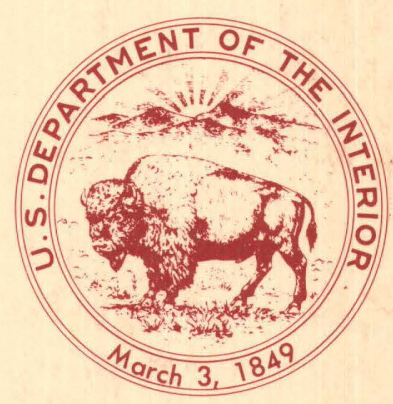





\section{Mineral Resources of the Eastern Pioneer Mountains, Beaverhead County, Montana}

By R. C. PEARSON, B. R. BERGER, H. E. KAUFMANN, W. F. HANNA, and E-AN ZEN 
DEPARTMENT OF THE INTERIOR

DONALD PAUL HODEL, Secretary

\author{
U. S. GEOLOGICAL SURVEY
}

Dallas L. Peck, Director

For sale by the

Books and Open-File Reports Section

U.S. Geological Survey

Federal Center

Box 25425

Denver, CO 80225

Library of Congress Cataloging-in-Publication Data

Mineral resources of the Eastern Pioneer Mountains, Beaverhead County,

Montana.

(U.S. Geological Survey bulletin ; 1766)

Bibliography: $p$.

Supt. of Docs. no.: I 19.3:1766

1. Mines and mineral resources-Montana-Pioneer Mountains. 2. Oredeposits-Montana-Pioneer Mountains. 3. Geology-Montana-Pioneer

Mountains.

I. Pearson, Robert Carl, 1926-

QE75.B9

no. 1766

II. Series.

$557.3 \mathrm{~s}$

[553'.09786'69]

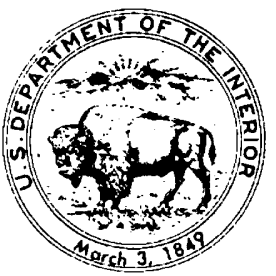

[TN24.M9] 


\section{CONTENTS}

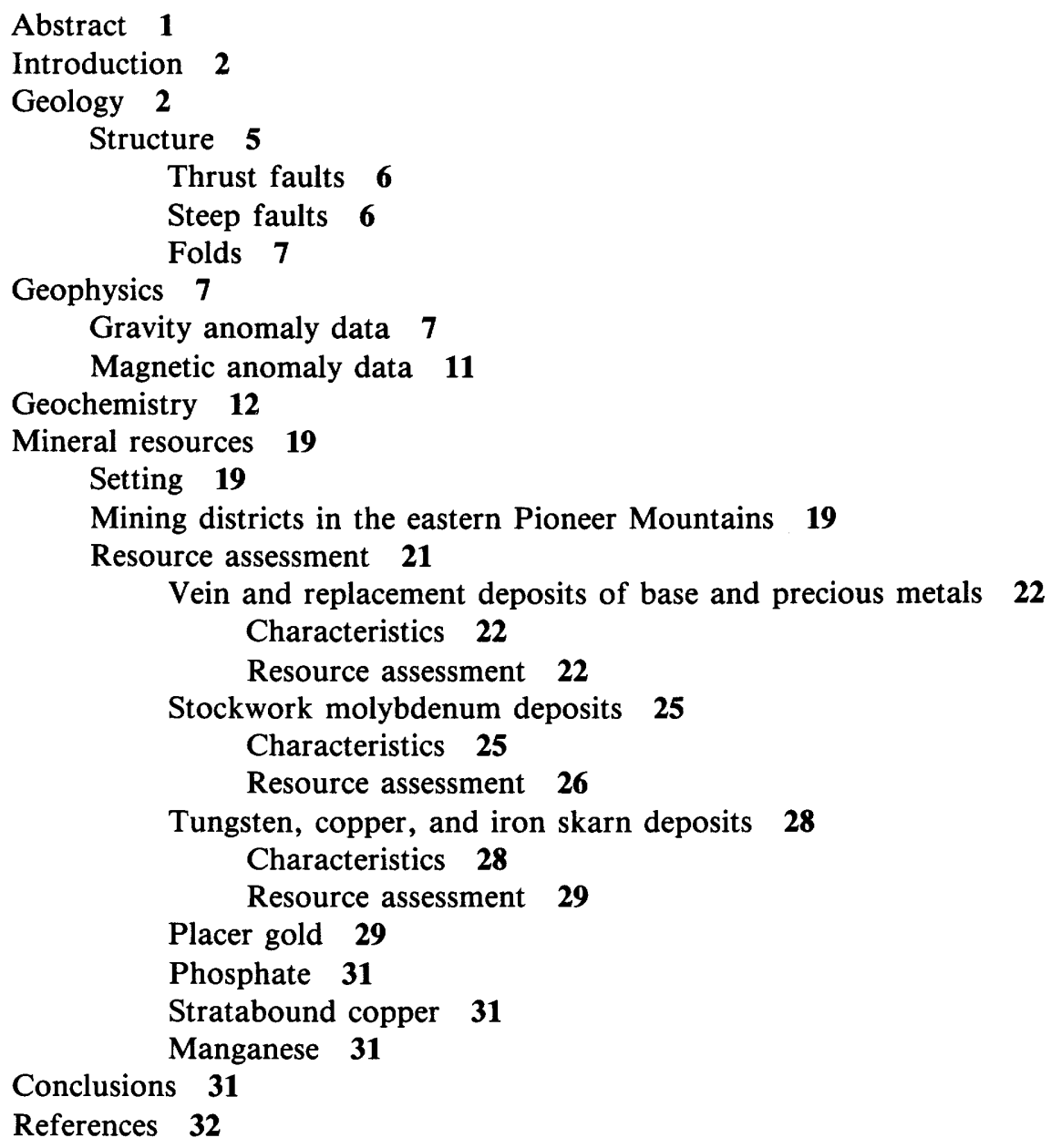




\section{FIGURES}

1. Map of eastern Pioneer Mountains, Beaverhead County, Montana, and vicinity 3

2. Generalized geologic map of the eastern Pioneer Mountains, southwestern Montana 4

3. Gravity anomaly map 9

4. Aeromagnetic map 10

5. Distribution of copper in stream sediments 13

6. Distribution of zinc in stream sediments 14

7. Distribution of lead in stream sediments $\mathbf{1 5}$

8. Distribution of molybdenum in stream sediments $\mathbf{1 6}$

9. Distribution of arsenic in stream sediments 17

10. Distribution of antimony in stream sediments 18

11. Mineral potential map-vein and replacement deposits of base and precious metals 23

12. Mineral potential map-molybdenum stockwork deposits 27

13. Mineral potential map-skarn deposits of tungsten, copper, and iron; phosphate deposits; and manganese deposits $\mathbf{3 0}$

14. Summary of mineral resource potential $\mathbf{3 3}$

\section{TABLES}

1. Magnetic properties of hand samples from the Pioneer Mountains 8 


\title{
Mineral Resources of the Eastern Pioneer Mountains, Beaverhead County, Montana
}

\author{
By R. C. Pearson, B. R. Berger, H. E. Kaufmann, \\ W. F. Hanna, and E-An Zen
}

\begin{abstract}
A mineral resource assessment of the higher central part of the eastern Pioneer Mountains, Beaverhead County, southwest Montana, has been made using new data from geological, geophysical, and geochemical surveys. The area has a long history of mining, and numerous small mining districts and many other mines and prospects within or adjacent to the area studied indicate that the Pioneer Mountains are well mineralized.
\end{abstract}

The eastern Pioneer Mountains are occupied largely by the Pioneer batholith and satellitic plutons of Laramide (latest Cretaceous and possibly early Paleocene) age that intruded sedimentary strata ranging from Middle Proterozoic age (Belt Supergroup), through Paleozoic, to Mesozoic age. The sedimentary rocks, which are preserved only at the north and south ends of the area, were folded and thrust faulted prior to Laramide intrusion. Movement along steep faults has continued through the Tertiary, providing for local preservation in down-faulted blocks of Tertiary detrital and tuffaceous sediments. A few small remnants of Tertiary lava flows also remain.

The mineral survey has shown that the area contains much evidence of mineralization, and numerous tracts within the area have been assigned various degrees of mineral potential for several mineral deposit types, namely: (1) vein and replacement deposits of base and precious metals, (2) stockwork molybdenum deposits, (3) skarn deposits of tungsten, copper, and iron, and (4) phosphate. Each tract is accorded a high $(H)$, moderate $(M)$, or low $(L)$ potential for the occurrence of deposits depending on the degree to which the tract corresponds to certain critical geologic, geochemical, and geophysical features of nearby mines and mining districts. Some evidence suggests the area has potential for placer gold, stratabound copper, and manganese deposits but no specific tracts are designated.

The most productive vein and replacement deposits in the eastern Pioneer Mountains are in carbonate rocks within a mile of plutons, although some vein deposits are in noncarbonate sedimentary and in plutonic rocks. Eight areas are especially favorable for vein and replacement deposits: (1) Sheep Creek-Clifford Creek, $(M)$-carbonate rocks adjacent to two granite plutons in the northern part of the area; (2) Moose
Creek-Canyon Creek, (M)-an east-trending belt that contains carbonate rocks adjacent to the north edge of the Pioneer batholith and includes the Hecla mining district; (3) Polaris mine window, $(M)$ - folded and faulted carbonate rocks exposed in a window through a major thrust and adjacent to the Pioneer batholith; (4) Baldy Mountain mining district, (M)-similar rocks and structure to Polaris mine window; (5) Cat Creek, (L)-upper plate Paleozoic carbonate rocks adjacent to the Pioneer batholith; (6) Elkhorn district, (M)-numerous quartz veins in the Pioneer batholith; veins are in fractures along and near a major fault; (7) Boatman Lake, (L)-a few pyritic quartz veins and an area of hydrothermal alteration; and (8) Schulz Lake, $(M)$ - northeast-trending veins within the Pioneer batholith.

Stockwork molybdenum deposits are generally closely associated with high-level granitic intrusions. The explored but unmined Cannivan Gulch deposit $2 \mathrm{~km}$ east of the area is partly within such a pluton and partly in silicated Paleozoic carbonate country rocks. Proterozoic quartzite is host to molybdenumbearing stockworks at other prospects in the Pioneer Mountains. Areas most favorable for molybdenum stockwork deposits, in order of decreasing potential, are: (1) Black Lion, (H)-exposed molybdenum-bearing vein cluster in the south portion of a small granite stock; (2) Elkhorn district, $(\mathrm{H})$ molybdenite-bearing quartz veins beneath silver-bearing veins in the Pioneer batholith; (3) Jacobson Meadows, (M)-quartzvein stockwork that contains traces of molybdenite in the Pioneer batholith and associated quartz porphyry dikes; (4) Pear Lake, $(M)$-molybdenite-bearing greisenlike pods and veins and a propylitically altered breccia pipe in Pioneer batholith; (5) Hecla district, (L)-an inferred favorable environment associated with a buried pluton beneath lead-silver vein and replacement deposits that contain rare molybdenite; (6) Moose Creek, (L)-limonitic quartz-vein stockwork in Proterozoic quartzite adjacent to a granite stock; and (7) Dubois Creek, (L) - weakly mineralized breccia pipe in the Pioneer batholith.

Skarn deposits of tungsten, copper, or iron occur in various Paleozoic carbonate formations at the contact with several plutons. These areas are mainly along the north and south margins of the batholith. Their potential is rated low. Phosphatic shale in the Phosphoria Formation is present in a small area in the northeast part of the area. The grade and thickness are submarginal under current economic conditions, and the structural setting would complicate mining. The placer 
gold potential of the eastern Pioneer area is low. Only small amounts of stream gravel are present downstream from known or potential lode sources. A single small occurrence of stratabound copper in Belt quartzite is not sufficient to warrant delineation of areas of potential. The manganese content of certain beds in the Dinwoody Formation is geochemically anomalous, but the grade is probably too low for these beds to be considered a manganese resource.

\section{INTRODUCTION}

This assessment of the mineral resources of a part of the eastern Pioneer Mountains, Beaverhead County, Mont., has been made principally to facilitate governmental decisions that affect the use of the public lands and for the use of that part of the general public interested in mineral exploration. To make the assessment, results of our studies of the geology, geochemistry, and geophysics have been considered together with available information on nearby mining districts. This report presents the assessment of the mineral resource potential of the area as a whole and our attempts to locate specific geologic tracts that seem permissive or prospective for the occurrence of mineral deposits of the types interpreted by us to be the most likely to have formed in the various geologic environments present.

The eastern Pioneer area, as the area studied is referred to, is composed of the higher central part of the eastern Pioneer Mountains (fig. 1). It is largely within Beaverhead National Forest and comprises national forest land except for patented mining claims, mainly clustered in several mining districts, and a fringe of other federal, state, and private lands along the southwest margin. The area is located about $50 \mathrm{~km}$ southwest of Butte and $30 \mathrm{~km}$ northwest of Dillon, in southwestern Montana. The Pioneer Mountains are a subcircular mountain mass almost completely surrounded by the broad alluviated valleys of the Big Hole and Beaverhead Rivers. The valleys of the north-flowing Wise River and south-flowing Grasshopper Creek divide the Pioneer Mountains into two lobes, of which the eastern half is the higher and more rugged. The area is forested except for numerous high peaks along the north-trending crest that are above timberline and some south-facing sage- and grass-covered slopes. Torrey and Tweedy Mountains at altitudes above $11,000 \mathrm{ft}$ are the highest in the region. Many of the valleys that head against the crest of the range have been glaciated, and moraines blanket some valleys and lower slopes.

Some geographic names mentioned in this report cannot be shown on the accompanying figures because of their small scale. These localities may be found on larger scale topographic quadrangle maps.

\section{GEOLOGY}

The eastern Pioneer area is formed mostly of the
Pioneer batholith, a composite body of Late Cretaceous to early Paleocene age that has intruded and to varying degrees metamorphosed sedimentary rocks deformed previously by folding and faulting (fig. 2). A few plutons are arranged satellitically around the batholith, and consanguineous and younger (Eocene and Oligocene) lava flows, more common outside the study area, remain as small erosional remnants. The area is within but near the eastern edge of the Montana thrust belt. Sedimentary rocks to the north, east, and south of the batholith range in age from Middle Proterozoic to Late Cretaceous. Those of Proterozoic age are allochthonous; they rest in thrust fault contact on highly deformed Paleozoic and Mesozoic strata. Detrital and tuffaceous deposits at least partly of Oligocene age are preserved in fault blocks along the Wise River in the northwest part of the area and in the southwest part of the area.

The oldest rocks exposed in the area are granitic gneiss and amphibolite of Early Proterozoic age (Arth and others, 1977). They crop out at the north end of the area in fault contact with the Proterozoic or Cambrian Black Lion Conglomerate. Because of scale limitations, the Black Lion is combined on figure 2 with the Middle Proterozoic Missoula Group. In this area the Missoula Group rocks have been subdivided by Pearson and Zen (1985) into five informal units believed to be largely, if not entirely, Mount Shields Formation, which consists mainly of quartzite, much of which is feldspathic and commonly pink, except where metamorphosed, and minor conglomerate, siltite, and argillite. The Black Lion, mostly matrix-supported pebble conglomerate, is overlain by about $300 \mathrm{~m}$ of quartzite that resembles somewhat rocks of the Mount Shields Formation in higher thrust plates nearby; however, the stratigraphic and structural relations among the Black Lion, the overlying quartzite, and the Mount Shields have not been definitely determined.

In the northern part of the area, strata assigned to the Middle Cambrian Silver Hill Formation, which consists of an upper member of silty and sandy carbonate rocks and a lower member of dark argillite and thin to very thin bedded quartzite, are apparently conformable on the quartzite that overlies the Black Lion or, in the absence of the quartzite, on the Black Lion itself. In the southeastern part, strata similar to the lower member of the Silver Hill seem to be conformable on Missoula Group strata, but in the southwestern part, at the base of Cambrian strata, well-sorted, medium-grained, thick- to thinbedded white quartzite $30 \mathrm{~m}$ or more thick is assigned to Flathead(?) Quartzite; its base is not exposed. Paleozoic strata overlying the Silver Hill are generally comparable-though not necessarily correlative-in the northern and southern parts of the area. As mapped in the northern part, they include, in ascending order: Middle and Upper Cambrian Hasmark Formation, dolomite 


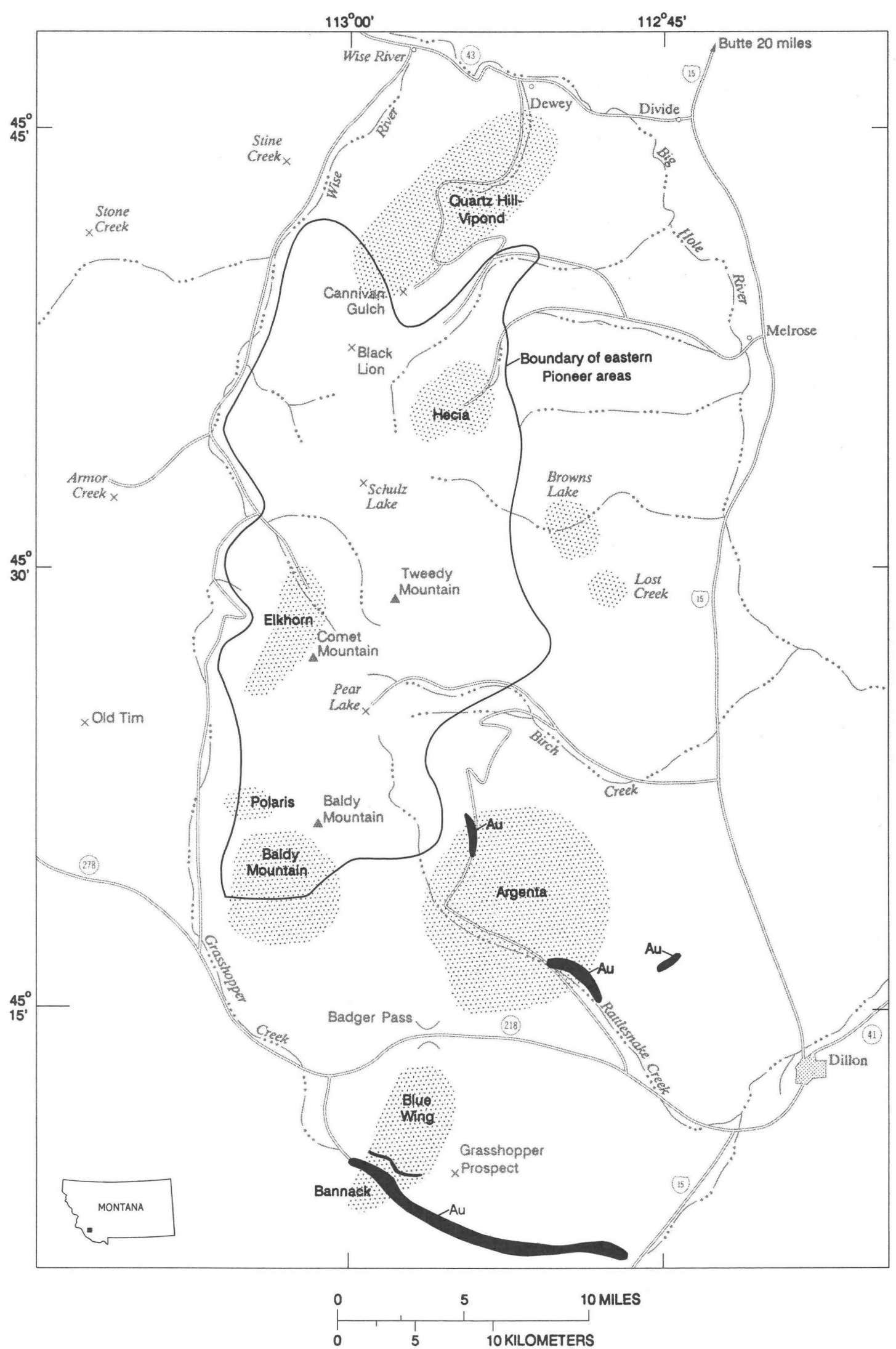

Figure 1. Map of eastern Pioneer Mountains and vicinity showing eastern Pioneer area, mining districts (dot pattern), some mines and prospects outside mining districts $(\mathrm{x})$, and gold placers (black pattern marked $A u)$. 


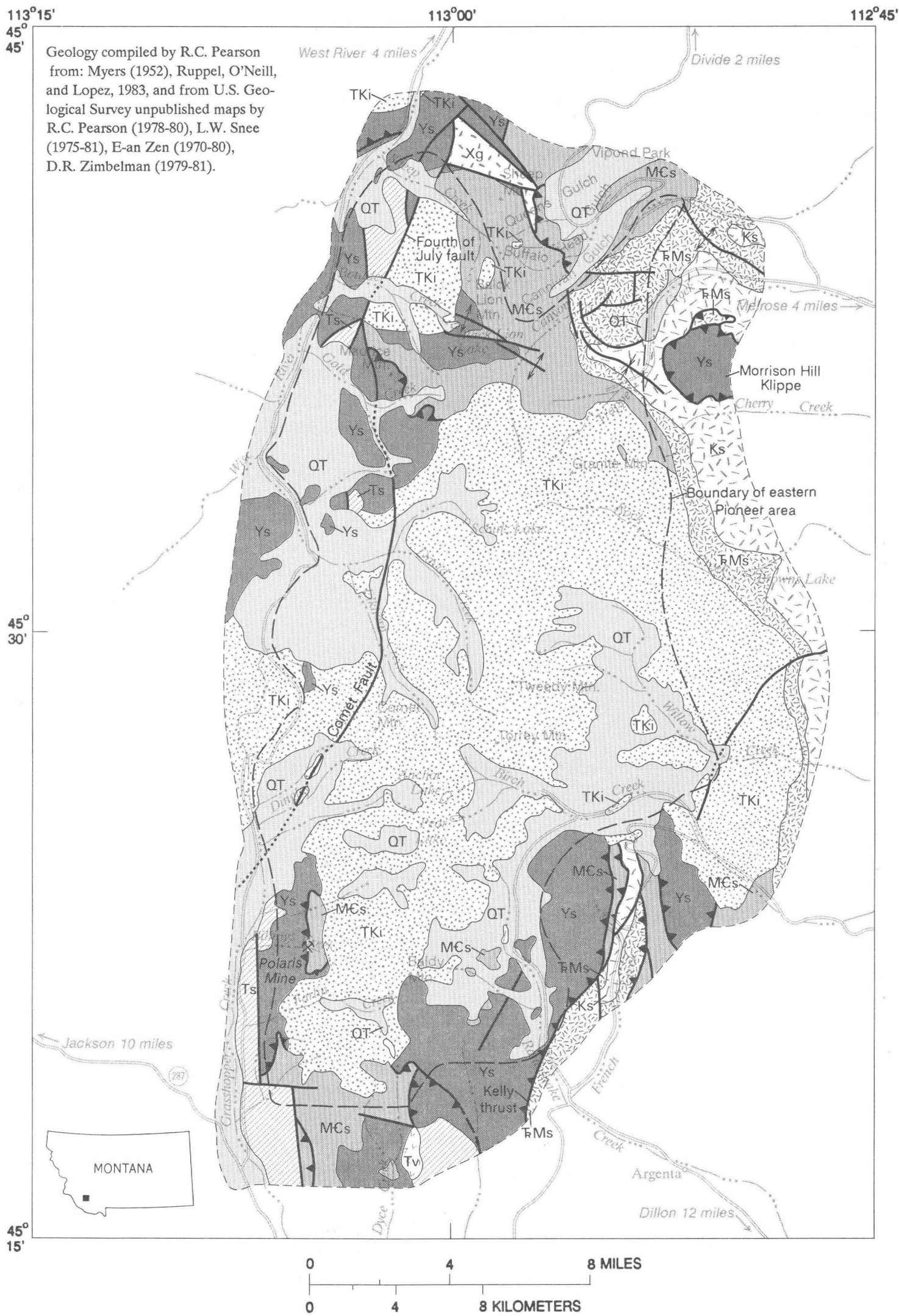

Figure 2(above and facing page). Generalized geologic map of the eastern Pioneer Mountains, southwestern Montana. 


\section{EXPLANATION}

OT

Ts

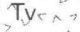

术

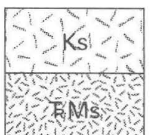

Mes
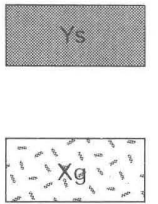

Contact

- Fault

Thrust fault, teeth on upper plate

Boundary of eastern Pioneer area

- Edge of geologic map

200-300 m thick; Upper Cambrian Red Lion Formation, carbonate and noncarbonate detrital rocks 0-20 m thick; Upper Devonian Jefferson Dolomite, gray fetid dolomite about 150-200 m thick; Upper Devonian Three Forks Formation, shaly carbonate $0-30 \mathrm{~m}$ thick; Lower Mississippian Lodgepole Limestone, thin-bedded gray limestone 100-150 m thick; Upper and Lower Mississippian Mission Canyon Limestone, massive limestone about $300 \mathrm{~m}$ thick; Mississippian and Pennsylvanian Amsden Formation, carbonate rocks and noncarbonate detrital rocks to $100 \mathrm{~m}$ thick; Pennsylvanian Quadrant Quartzite, fine-grained clean quartzite 150-200 m thick; and Permian Phosphoria Formation, dolomite, chert, sandstone, and phosphatic shale to $100 \mathrm{~m}$ thick. Mesozoic strata in the northeastern part of the area include: Lower Triassic Dinwoody Formation, shale and siltstone, some calcareous, silty limestone, and sandstone about $150 \mathrm{~m}$ thick; Lower Cretaceous Kootenai Formation, sandstone and local conglomerate in lower part, shale and limestone in middle and upper parts $200 \mathrm{~m}$ thick; and Upper and Lower Cretaceous Colorado Group, of which the lower $50 \mathrm{~m}$ within the area is mainly light-tan, olive, and gray slightly calcareous feldspathic sandstone.

The Pioneer batholith is composed of several plutons that range in composition from gabbro to granite (IUGS classification; Streckeisen, 1976). In the eastern Pioneer area, the most voluminous rock, comprising much of the core of the batholith, is hornblende-biotite granodiorite. Various plutons, ranging from biotite granite to hornblende tonalite, are along the northern edge of the batholith, and hornblende gabbro occupies a similar marginal position on the southwest. In the northern tip of the area, two stocks of biotite granite locally contain muscovite believed to be partly magmatic and partly hydrothermal. Small mafic dikes that have intruded both sedimentary and plutonic rocks are at least partly of Eocene age and related to nearby volcanic rocks (Snee, 1982).

\section{Structure}

The Pioneer Mountains are within the Cordilleran fold and thrust belt and near its eastern and leading edge. The transition from the fold and thrust belt eastward into the Rocky Mountain foreland province is poorly defined but is probably less than $30 \mathrm{~km}$ east of the Pioneer Mountains. Although the eastern Pioneer Mountains are occupied chiefly by the Pioneer batholith and other smaller plutons, stratified rocks that record folding and faulting are exposed at the north and south edges of the area. The nature and distribution of structures in the vicinity of the eastern Pioneer Mountains have been determined in large part by geologic mapping by Richards and Pardee (1925), Myers (1952), Fraser and Waldrop (1972), E-an Zen (unpublished mapping, 1970-78), and D. R. Zimbelman (unpublished mapping, 1978-80).

The structural style of the Proterozoic sedimentary rocks contrasts with those of Paleozoic and Mesozoic age. Proterozoic strata are in two thrust sheets structurally above the younger strata. The Proterozoic rocks are gently folded whereas the younger ones are much more complexly folded-locally isoclinally and disharmonically. In general, the intensity of folding decreases eastward away from the thrust faults and perhaps away from the batholith contact as well. High-angle faults of various trends displace rocks of all ages as young as Oligocene. The principal steep faults compose the Comet-Fourth of July fault zone that ranges from about north to N. $30^{\circ}$ E. along the west side of the area.

Pre-Cenozoic stratified rocks in the eastern Pioneer Mountains were folded and thrust faulted during the time between deposition of the Early and Late Cretaceous Colorado Group and intrusion of the latest Cretaceous Pioneer batholith and related plutons. Isotopic age determinations and meager fossil evidence suggest the possibility that deposition of the Colorado Group may have partly overlapped the structural and intrusive events. Faulting continued through the Cenozoic, changing in style to high-angle block faulting that in time delineated the basins and ranges in existence today. 
Thrust Faults

The distribution and attitude of thrust faults that have been mapped to the north (Fraser and Waldrop, 1972), east (E-an Zen, unpublished mapping 1970-78), and south (Myers, 1952) of the study area illustrate a consistent relation of Belt quartzite and argillite in one or more thrust sheets that moved presumably eastward over crumpled and overturned Paleozoic and Mesozoic sedimentary rocks. Imbricate slices of Phanerozoic rocks are common in the thrust zone or ahead of the leading edge, such as along the Johnson thrust (Moore, 1956; Fraser and Waldrop, 1972) and beneath the Morrison Hill klippe (fig. 2). To the southeast, Myers (1952) has mapped the Kelley thrust in which Proterozoic quartzite is thrust over folded and imbricated Paleozoic and Mesozoic rocks. The Kelley thrust, which is shown on figure 2, terminates northward against the Pioneer batholith.

Within the eastern Pioneer area, thrust faults, perhaps parts of a single thrust sheet, are exposed (1) near the head of Gold Creek northwest of the batholith, (2) near the Polaris mine (fig. 2) at the southwest margin of the batholith, and (3) in a structurally complex area south of the batholith. In each of these areas the lower plate rocks are folded calcareous and sandy strata of definitely Paleozoic or probable Paleozoic age that, as a result of being only $1-2 \mathrm{~km}$ from the batholith, are metamorphosed in varying degrees to marble, quartzite, and calc-silicate hornfels.

The metamorphosed rocks in the lower plate are clearly recognizable as to formation in the Gold Creek area. The base of the tightly to gently folded lower Paleozoic formations seems to be in depositional contact with quartzite of Cambrian and (or) Proterozoic age near Grace Lake and in the valley of the south fork of Boulder Creek. On the north flank of Maurice Mountain, the thrust cuts up-section toward the east. At its western end, where it is terminated against the Fourth of July fault, it is in the Hasmark Formation, and from there eastward it transgresses upward through the Red Lion Formation and into the Jefferson Formation at its eastern trace, which continues southeast and terminates against the batholith. If this thrust continued to rise through the section toward the east, in the $11 \mathrm{~km}$ to the Morrison Hill klippe it reasonably could have transgressed up into the Cretaceous. Hence, the thrust at the base of the klippe is possibly the same as the one in the Gold Creek area. Possibly, these thrust segments are parts of the Kelley thrust, which is south of the batholith.

The rocks exposed in the window at the Polaris mine (fig. 2) have been intruded on their east side by the Pioneer batholith, and the upper plate Middle Proterozoic rocks have been largely removed from the east side. Relations at the north end of the window, however, are interpreted to indicate that the thrust and overlying Middle
Proterozoic rocks, which adjacent to the thrust are quartzose spotted hornfels, are anticlinal, suggesting arching after thrusting. Relations at the south end, however, indicate that the Paleozoic limestone there has been thrust over Proterozoic quartzite, and the limestone contains thin thrust slices of the quartzite. Thus, the entire block of Paleozoic rocks could be an imbricate slice, underlain as well as overlain by Proterozoic rocks. The fault bounding the west side of the window seems to be steep and is interpreted as a later normal fault that has offset the thrust. Most of the Paleozoic rocks within the window have not been identified as to formation, but light- to medium-gray, massive to thin-bedded, calcitic marble at the south end of the window is believed to be partly Mississippian Mission Canyon Limestone. Massive dolomitic marble at the north end of the Polaris mine window contains one or more beds of quartzite 2-6 m thick and one or more beds of black calc-silicate hornfels up to $2 \mathrm{~m}$ thick. These rocks are probably Cambrian but could include some Upper Devonian Jefferson Dolomite.

A similar relationship about $3 \mathrm{~km}$ southwest of the Polaris mine window reveals Proterozoic quartzite overlying and adjacent to brecciated yellowish dolomitic marble that grades southward into medium- to dark-gray fetid dolomite assigned to Jefferson Dolomite. Other rocks of Cambrian and Devonian age south of the batholith are interpreted to be in the lower plate of this same thrust, which is exposed east of East Fork Dyce Creek. The Paleozoic sedimentary rocks south of the batholith are also interpreted to lie in thrust contact on Proterozoic quartzite, and thrusts have also been mapped within the Paleozoic sequence by D. R. Zimbelman (written commun., 1981).

\section{Steep Faults}

High-angle faults of various orientations, including numerous fracture zones within the plutonic rocks, are scattered widely in the eastern Pioneer area. The principal structures of this type are the Comet fault and the Fourth of July fault. The Comet fault at the west base of Comet Mountain is described by Geach $(1972$, p. 107) as the dominant structure in the Elkhorn mining district. In the mines, the Comet fault has been shown to dip west about $45^{\circ}$, which prompted Geach (1972) to conclude that the steep west face of Comet Mountain is a fault scarp. Although no direct evidence for faulting was found on the face of the mountain, mid- to late-Tertiary movement seems likely, and the abrupt topographic rise of the mountain above the fault trace could indeed have resulted from late movement. Quaternary moraines cross the Comet fault with no perceptible offset. Movement along the Comet fault prepared the ground for the formation of the many veins in the Elkhorn district. Brecciated and recemented veins give evidence of repeated movement and several periods of mineralization. The continuation of the 
Comet fault to the north seems to intersect the Fourth of July fault (Calbeck, 1975) at an acute angle north of Gold Creek. The Fourth of July fault marks the east side of a graben that locally contains tuffaceous and epiclastic sediments. A late Oligocene fission-track age of $27.0 \pm 1.3$ m.y. has been determined on zircon (C. W. Naeser, written commun., 1979) from tuff in similar deposits south of Gold Creek. This suggests Oligocene and later movement on these graben faults.

\section{Folds}

Paleozoic and Mesozoic stratified rocks have been tightly folded in contrast to the Proterozoic rocks in which folds are open and gentle. Folds are of several styles and sizes including northwest-trending folds with wavelengths and amplitudes of $2-4 \mathrm{~km}$, as in the northern part of the area, close-spaced tight folds, as at the southwest corner of the mapped area, and a dome in the Hecla mining district.

The large northwest-trending folds were first mapped by Richards and Pardee (1925). Within the eastern Pioneer area (fig. 2), two folds typical of this group are a southeast-plunging syncline west of Morrison Hill klippe that contains beds as young as the Colorado Group and, in the central part of the map north of the batholith, an anticline that plunges southeast; the flanks and crests of some of these folds have been faulted.

North-trending smaller folds (too small and numerous to be shown on fig. 2) are in rocks of the lower plate a short distance beneath thrust faults at two places. East of the thrust north of Gold Creek (fig. 2), symmetrical to slightly east-verging folds are in lower Paleozoic formations. Smaller folds near the southwest corner of the mapped area are in Jefferson Dolomite (D. R. Zimbelman, written commun., 1981).

The dominant structure in the Hecla area is a complex eroded dome. The complexity is denoted by thinning of all formations on the flanks of the dome and by isoclinal, disharmonic subsidiary folds on its southwest flank. Folding on the north flank also was noted by Karlstrom (1948) underground in workings of the CleveAvon mine; however, the structure of much of the periphery of the dome is masked by till and scree, and the details are obscure. Karlstrom (1948) concluded that the dome was formed by forceful intrusion of an offshoot of the Pioneer batholith because of increased metamorphism in pelitic rocks in the core of the dome. The batholith intrudes the south and southeast flanks of the dome approximately concordantly, but only a few sills intrude the sedimentary rocks within the dome. An aeromagnetic map (U.S. Geological Survey, 1979) shows a "magnetic nose" plunging northwest beneath the dome, suggesting a bulge in the batholith contact rather than a cupola. Some expression for this bulge is evident in the surface contact of the batholith. Thus, the batholith itself, which is only a kilometer from the center of the dome on its southeast side, rather than a cupola rising from much greater depth, could have caused the increase in metamorphic grade. In fact, the grade is higher on the southeast side, and this grade is comparable to that in rocks of similar composition elsewhere at the batholith contact. The dome is along the trend of an anticline and may be a culmination on its crest.

\section{GEOPHYSICS}

On a regional scale, gravity and magnetic anomaly data in the eastern Pioneer Mountains are principally useful for delineating the subsurface boundaries of the Pioneer batholith and for providing insight about the depths of basin fill. On a local scale, the geophysical data serve as indicators of compositional changes within a rock unit, including, most importantly, rock alteration. The magnetic anomalies are associated with large magnetization contrasts between plutonic and sedimentary or altered rocks; the gravity anomalies are associated with either large density contrasts between basin fill and surrounding rocks or smaller density contrasts between plutonic and sedimentary or between altered and unaltered rocks. The induced and remanent magnetizations and dry bulk densities of 30 representative rock samples collected by H. E. Kaufmann and E-an Zen are summarized in table 1 .

\section{Gravity Anomaly Data}

A reconnaissance gravity survey conducted by H. E. Kaufmann and colleagues in the U.S. Geological Survey during the summers of 1978 and 1979 consists of 105 stations established on foot or by land vehicle using a LaCoste and Romberg geodetic gravity meter. Observed gravity values are in reference to base station WA-123 of the World Relative Gravity Reference Network (Defense Mapping Agency, 1974) at the Butte, Mont., airport; data were reduced using a density of $2.67 \mathrm{~g} / \mathrm{cm}^{3}$ and terrain corrections were made to a distance of $166.7 \mathrm{~km}$ from each station.

The study area is characterized by a regional arcuate pattern of gravity anomaly contours (fig. 3); these contours follow the exposed eastern contact of the Pioneer batholith and appear to outline the northeastern and southeastern margins of the batholith where it is partly covered by sedimentary rocks and valley sediments. As a convenient guideline, the " -210 mgal" contour appears to approximately mark the northeastern, eastern, and southeastern edges of the batholith. A significant 
Table 1. Magnetic properties of hand samples from the Pioneer Mountains.

[Rem J , magnitude of remanent magnetization, $\times 10^{-5} \mathrm{emu} / \mathrm{cm}^{3} ; \mathrm{K}$, intrinsic magnetic susceptibility, $\times 10^{-5} \mathrm{emu} / \mathrm{cm}^{3} ;$ Ind J, magnitude of induced magnetization, $\times 10^{-5} \mathrm{emu} / \mathrm{cm}^{3}$; Q, Koenigsberger ratio of magnitudes of remanent magnetization to induced magnetization; $\rho$, dry bulk density, $\mathrm{g} / \mathrm{cm}^{3}$; J-type of likely anomaly source, type of magnetization which is sufficiently strong (at least $10^{-3} \mathrm{emu} / \mathrm{cm}^{3}$ ) to serve as a source for high-amplitude anomalies; R, remanent magnetization; I, induced magnetization; NON, relatively nonmagnetic]

\begin{tabular}{|c|c|c|c|c|c|c|c|}
\hline $\begin{array}{l}\text { Sample } \\
\text { number }\end{array}$ & $\begin{array}{c}\text { Rem } \\
\mathrm{J}\end{array}$ & K & Ind & Q & $\rho$ & $\begin{array}{l}\text { J-type of } \\
\text { likely } \\
\text { anomaly } \\
\text { source }\end{array}$ & Remarks \\
\hline 925 & 0.3 & 0.8 & 0.4 & 0.616 & 2.60 & NON & Clean, white quartzite from Maurice Mtn. \\
\hline 926 & 0.2 & 1.8 & 1.0 & 1.84 & 2.67 & NON & Diorite? from Black Lion Mtn. \\
\hline 927 & 59.3 & 177.9 & 102.3 & .580 & 2.65 & I & Dark granite from Granite Mtn. \\
\hline 928 & 144.0 & 329.6 & 189.5 & .760 & 2.76 & $\mathrm{R}, \mathrm{I}$ & Dark granite on a ridge $1 \mathrm{~km}$ north of Granite Mtn. \\
\hline 930 & 0.1 & 0.2 & 0.1 & .806 & 2.61 & NON & Quartzite from a peak $3.2 \mathrm{~km}$ south of Maurice Mtn. \\
\hline 931 & 21.2 & 275.2 & 158.2 & .134 & 2.62 & I & Quartz diorite from a ridge $1 \mathrm{~km}$ northeast of Barb Mtn. \\
\hline 932 & 1.6 & 244.5 & 140.6 & .012 & 2.62 & I & Quartz diorite from a ridge $3 \mathrm{~km}$ east of Torrey Mtn. \\
\hline 935 & 3.0 & 206.7 & 118.8 & .025 & 2.59 & I & Granodiorite from a ridge $2 \mathrm{~km}$ west of Torrey Mtn. \\
\hline 936 & 58.5 & 64.9 & 37.3 & 1.57 & 2.58 & NON & Granodiorite from Comet Mtn. \\
\hline 951 & 0.6 & 0.9 & 0.5 & 1.26 & 2.64 & NON & Quartzose sandstone from hill $8 \mathrm{~km}$ south of Stine Mtn. \\
\hline 952 & 0.3 & 0.2 & 0.1 & 1.86 & 2.59 & NON & $\begin{array}{l}\text { Reddish quartzite from mountain } 3.2 \mathrm{~km} \text { east-southeast of } \\
\text { Stine Mtn. }\end{array}$ \\
\hline 953 & 0.2 & 0.6 & 0.4 & .606 & 2.61 & NON & Quartzite from Stine Mtn. \\
\hline 967 & 0.2 & 1.0 & 0.6 & .336 & 2.57 & NON & Quartzite from small peak $5.6 \mathrm{~km}$ east of Stine Mtn. \\
\hline 1053 & 6.0 & 245.6 & 141.2 & .042 & 2.60 & I & Hornblende-biotite granodiorite. \\
\hline 1055 & 0.4 & 2.7 & 1.6 & .242 & 2.70 & NON & Quartzite south of Baldy Mtn. \\
\hline $8 \mathrm{~B} 1$ & 28.2 & 501.9 & 288.6 & .098 & 3.24 & I & Mafic rock from near base of Granite Mtn. \\
\hline Z-347 & 0.2 & 103.7 & 59.6 & .003 & 2.62 & NON & From siliceous sill $2 \mathrm{~km}$ north of Granite Mtn. \\
\hline $\mathrm{Z}-32$ & 0.3 & 1.5 & 0.9 & .380 & 2.58 & NON & Muscovite granite $2 \mathrm{~km}$ northwest of Black Lion Mtn. \\
\hline $\mathrm{Z}-500$ & 0.7 & 83.2 & 47.8 & .015 & 2.63 & NON & Muscovite granite $2 \mathrm{~km}$ northwest of Black Lion Mtn. \\
\hline Z-644 & 0.4 & 4.0 & 2.3 & .154 & 2.59 & NON & Dolostone $3 \mathrm{~km}$ northwest of Granite Mtn. \\
\hline Z-1 & 1.0 & 325.3 & 187.1 & .006 & 2.69 & I & "Granite" near Longbranch Lake. \\
\hline $\mathrm{Z}-31(5)$ & 4.6 & 269.6 & 155.0 & .030 & 2.80 & I & Mafic dike $3 \mathrm{~km}$ north of Granite Mtn. \\
\hline $\mathrm{Z}-41$ & 2.6 & 217.6 & 125.1 & .021 & 2.84 & I & Mafic dike $11 \mathrm{~km}$ northeast of Granite Mtn. \\
\hline Z-1044 & 0.2 & 1.2 & 0.7 & .233 & 2.62 & NON & Muscovite granite $5 \mathrm{~km}$ northwest of Sheep Mtn. \\
\hline Z-914 & 7.1 & 20.1 & 11.6 & .615 & 2.59 & NON & Volcanic rock west of Divide. \\
\hline Z-516 & 27.0 & 82.7 & 47.5 & .568 & 2.62 & NON & Porphyritic granite $4 \mathrm{~km}$ north of Black Lion Mtn. \\
\hline Z-744 & 0.6 & 161.3 & 92.7 & .007 & 2.65 & NON & Granite west of Browns Lake. \\
\hline Z-1298 & 0.5 & 292.6 & 168.2 & .003 & 2.69 & I & Granodiorite $3 \mathrm{~km}$ east of Seymore Mtn. \\
\hline Z-881 & 0.7 & 315.2 & 18.1 & .037 & 2.67 & NON & Granodiorite $3 \mathrm{~km}$ west of Long Branch Lake. \\
\hline Z 313 & 45.4 & 979.1 & 563.0 & .806 & 2.87 & I & Quartz diorite $4 \mathrm{~km}$ northwest of Granite Mtn. \\
\hline
\end{tabular}

departure from this spatial relationship occurs where aeromagnetic anomaly data (for example, the " 57,100 gamma" contour on fig. 4) and the geologic map (fig. 2 ) indicate that the batholith bulges east of the gravity contour guideline.

Gravity values of the arcuate pattern of anomaly contours decrease from east to west, indicating that the batholith progressively thickens westward. Part of this gradient may also be attributable to a decrease in maficmineral content toward the center of the batholith, a relationship which also appears to occur in the nearby Boulder batholith (Klepper and others, 1974) and Tobacco Root batholith (Smith, 1970). At the western edge of the study area, moderate to steep anomaly gradients with values decreasing westward are associated with a combination of batholith thickening and occurrences of thick basin fill.
The regional gravity anomaly gradient is interrupted in many places by short-wavelength, or local, anomalies (" $G$ " sites, fig. 3) associated with diverse density contrasts. A number of these short-wavelength anomalies reflect local occurrences of very low-density alluvial deposits which cover moderately low-density batholithic rocks. Where any two short-wavelength lows occur in proximity to one another, the region between the lows, being relatively higher, constitutes a residual high. In some places, a residual high caused by lowdensity materials on either side is difficult, if not impossible, to distinguish from a high caused by higher density material directly below. For example, the high G1, consisting of a nose that projects toward Granite Mountain, may be a residual high over plutonic rock not covered by valley sediments or may be a high caused by hidden relatively dense rocks, perhaps similar to gabbro or 


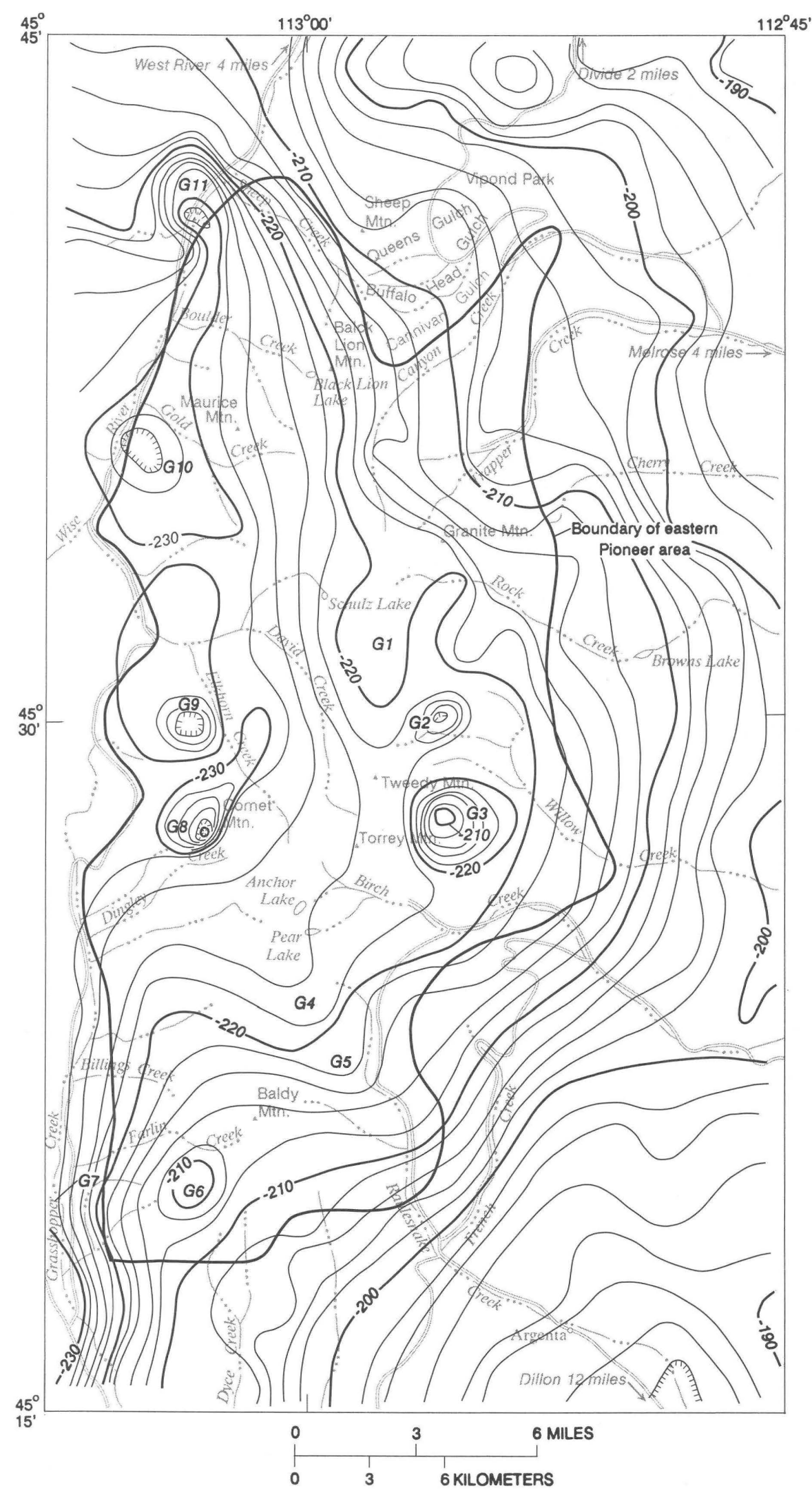

Figure 3. Gravity anomaly map. G1-G11 are anomalies discussed in text. Bouguer gravity anomaly contour compilation by H. E. Kaufmann and S. Sorensen, 1981. 


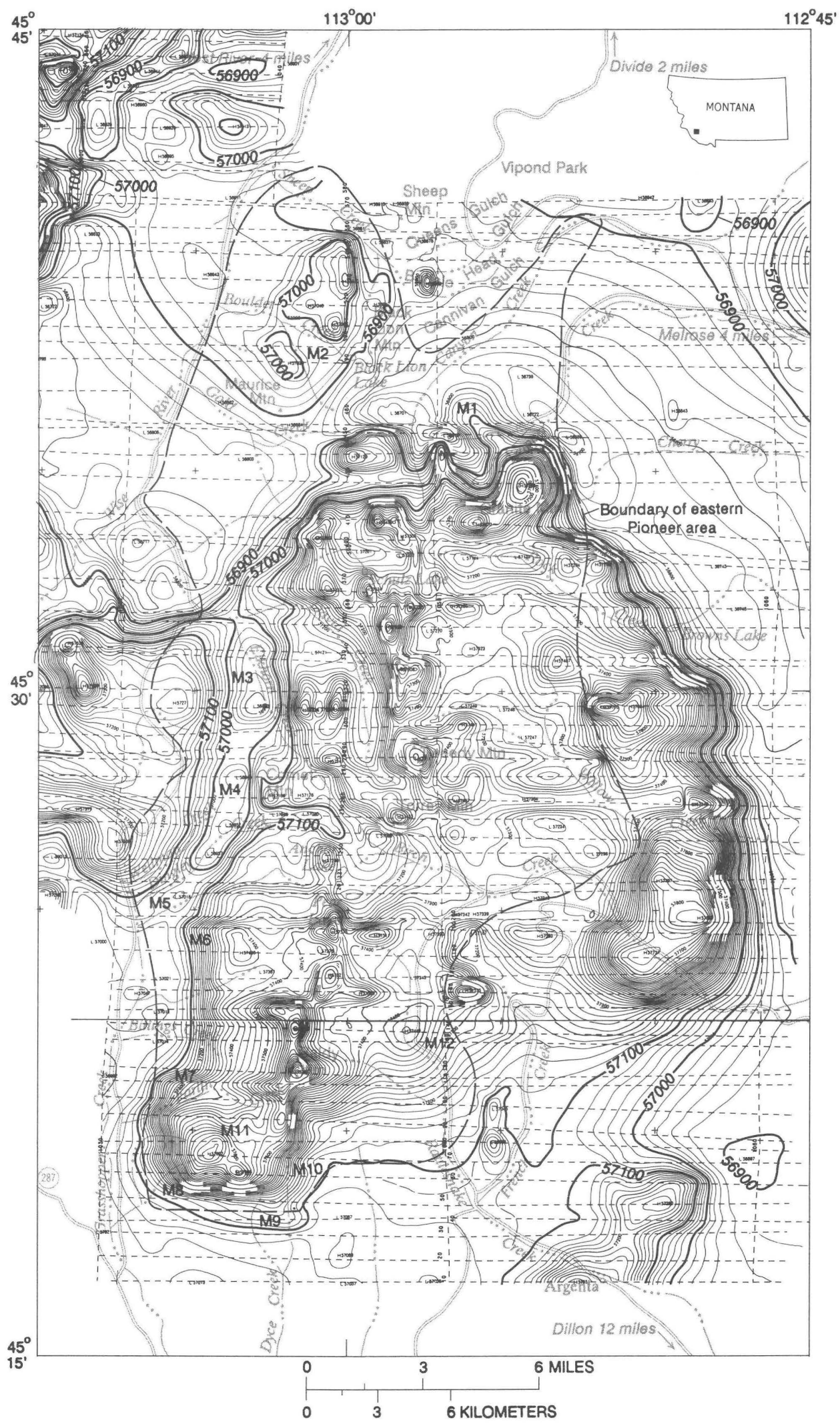

Figure 4. Aeromagnetic map. M1-M12 are anomalies discussed in text. 
pyroxenite which crops out on the east face of Granite Mountain in a body too small to be shown on figure 2 . Sample 8B1 in table 1 is representative of such a rock unit. Low $\mathrm{G} 2$ and high G3, both based principally on single measurements, may reflect, respectively, a local thickening of sediments and a residual high associated with plutonic rocks. Low G4, which broadly plunges over a region of short-wavelength magnetic highs, takes the form of a residual high which may be caused in part by intrusive rocks a little more mafic, magnetic, and dense than those nearby. Low G5 is somewhat enigmatic; although it is spatially associated in part with thermally metamorphosed Paleozoic carbonate rocks which would be expected to have a density equal to or slightly greater than peripheral batholithic rocks, it appears to be substantially influenced by low-density moraine deposits near Estler Lake. High G6 in the Baldy Mountain mining district is associated with gabbroic plutonic rocks. Steep gradient G7 is the eastern flank of a high-amplitude low associated with low-density basin fill along Grasshopper Creek; the fill has an estimated thickness of 3 to 4 $\mathrm{km}$. Low G8, within a magnetic trough nearly coincident with the Comet fault zone, may express subsurface gouge and fractured plutonic rocks within the fault zone. Low G9 is associated with a large glacial moraine just west of the Comet fault zone. Lows G10 and G11 are largely associated with exposed or inferred Tertiary sediments along the Wise River valley. Of special interest with respect to mineral occurrences, (1) low G5, though influenced by low-density moraine, may be caused, in part, by gouge or silicic intrusive rock within a region near Estler Lake inferred on the basis of geologic data to contain rocks and structures favorable to mineralization, and (2) low G8 is centered on the Elkhorn mining district.

\section{Magnetic Anomaly Data}

An aeromagnetic survey of the study area, conducted by Aero Service in 1978 under contract to the U.S. Geological Survey, consists of east-west flight lines spaced about $0.8 \mathrm{~km}$ apart at a barometric elevation of $2,740 \mathrm{~m}$. Anomaly values are based on the International Geomagnetic Reference Field 1975, updated to the month and year flown, to which a bias of 57,270 gammas has been added (U.S. Geological Survey, 1979).

The study area is characterized by an arcuate belt of high-amplitude magnetic highs forming the western two-thirds of a horseshoe-shaped anomaly belt, convex to the north-northwest, associated with high terrain of exposed Pioneer batholith (fig. 4). As a convenient guideline, the " 56,900 gamma" contour generally conforms to the eastern and northern margins of the batholith; in the northwestern part of the study area this contour line occurs in two segments, the region between them marking a narrow zone where plutonic rocks between two exposed plutons are deeply buried, altered, or absent altogether. The " 57,100 gamma" contour is also significant in that it outlines a smaller region, conforming to the southern margin of the batholith and expressing a possible thickening of the batholith not well expressed in the gravity anomaly data. In the western part of the study area where this contour line occurs in two segments, the region between them marks a north-south narrow zone of relatively nonmagnetic subsurface rocks-interpreted to be a major zone of alterationnearly coincident with the mapped trace of the Comet fault. Of interest to future modeling studies, the slightly southern displacement of the " 57,100 gamma" contour relative to the mapped outline of the batholith suggests that the average total magnetization (vector sum of induced and remnant magnetization) of the batholith has approximately the same direction and polarity as the ambient magnetic field. The average amplitude of the batholith anomaly is about 400 gammas.

The part of the horseshoe-shaped pattern of highamplitude magnetic highs which lies within the study area is almost exclusively associated with high terrain of batholithic rocks. The western part of the horseshoe lies above 2,740-m elevation and, therefore, the flight height of the survey was higher in that area; the eastern part (largely just outside the study area boundary) lies above the 2,440-m elevation. The numerous individual highs comprising the horseshoe as well as many accompanying lows developed over lower topography in the same batholithic rocks have no known special significance from the standpoint of economic geology, and they are not mentioned further. However, a number of lower amplitude anomalies in lower terrain (" $M$ "' sites, fig. 4), some having economic significance, are worthy of special note, and they are briefly discussed.

Anomaly M1 is typical of a high which noses from a region of plutonic rocks into adjacent sedimentary rocks, indicating that a relatively shallow lobe of plutonic rocks extends beneath the sedimentary rocks exposed at the surface. Anomaly M2 is unusual in that it is a low saddle which bisects a magnetic high developed over exposed plutonic rocks which are highly magnetic (the " 57,000 gamma" contour outlines the nearby magnetic rocks). The low is not attributable to low topography and, therefore, may be caused by alteration in the Black Lion mineralized area. Anomalies M3 through M5 are lows delineating a north-south magnetic trench, not influenced by the variable topography, which essentially coincides with the mapped Comet fault. This elongate magnetic depression is marked at its northern extremity by the Jacobson Meadows mineralized area (see p. 28), passes through the center of the Elkhorn mining district (fig. 1) and continues southward through the Wellman Creek mineralized area (see p. 25) to lat $45^{\circ} 25^{\prime} \mathrm{N}$. This magnetic 
feature expresses a major zone of suspected subsurface alteration of potential interest for future mineral exploration. Another magnetic pattern of special interest is that part of the steep magnetic gradient in the southwestern part of the study area which is not influenced by high terrain-notably, that part below 2,440 m elevation. Labels M6 through M10 outline this gradient, which transects mineralized areas including the Polaris district (fig. 1), the Driscoll Creek mineralized area, the Steel Creek-Dyce Creek area, and the Baldy Mountain mining district (fig. 1). The steep gradient forms the flanks of high-amplitude magnetic high M11, which is not augmented by high topography and which nearly coincides with gravity high G6, suggesting that this part of the batholith is more mafic than other parts within the study area, as indicated by the presence of gabbroic rocks. Magnetic high M12 is not influenced by topography; it approximately coincides with gravity low G5 of the Estler Lake area previously noted. It may be caused by magnetite enrichment of thermally metamorphosed rocks near the batholith-sedimentary rock contact.

In summary, while both gravity and magnetic anomaly data are useful for defining the extent of the Pioneer batholith and thicknesses of basin fill, magnetic anomaly data are especially useful for delineating anomalies which may indicate zones of suspected subsurface alteration. Of special interest are those areas characterized by anomalies or gradients not appreciably influenced by topography. Within the study area, the limited number of such magnetic features include two short-wavelength anomalies (M2 and M12), one elongate magnetic trough (M3 through M5), and one steep gradient (M6 through M10) (fig. 4). All of these features are spatially associated with discrete occurrences of mineralized ground.

\section{GEOCHEMISTRY}

A stream-sediment sampling program was conducted concurrently with the geological and geophysical studies to determine the distribution of elements of interest for mineral resource appraisal. Sediment samples were collected at 288 sites in active drainages throughout the study area; the samples were dried, sieved to a -200 mesh $(<75 \mu \mathrm{m})$, and analyzed for 31 elements in the laboratories of the U.S. Geological Survey. The methods of chemical analysis and analytical results are presented in Berger, Breit, and others (1979).

Samples of ore, altered rock, and soil were collected from selected mines and prospects throughout the study area and vicinity and analyzed. The purposes of this survey were to define the trace-element suites characterizing the various types of mineral deposits in the region and to evaluate the dispersion of pathfinder elements around mineralized areas. Analytical results and interpretations are presented in Berger, Van der Voort, and others (1979) and Pearson and Berger (1980). The distribution of copper, zinc, lead, molybdenum, arsenic, and antimony in the stream sediments is shown on figures 5-10.

Copper.-The highest concentrations of copper occur in three east- to northeast-trending belts that transect the study area (fig. 5). The northernmost belt extends from the Wise River north of Gold Creek through Cannivan Gulch to Vipond Park. In that belt, clusters of high concentrations occur in Boulder Creek below Black Lion Lake and in the vicinity of Cannivan Gulch. A central belt extends from Elkhorn Creek to Cherry Creek in which high values are found in Elkhorn and David Creeks and just north of Granite Mountain in the vicinity of the Hecla district (fig. 1). A southern belt extends from near Grasshopper Creek southwest of Comet Mountain through the Torrey Mountain area to Willow Creek and includes an area of high values in the lower reaches of Dingley and Wellman Creeks and in the upper Birch Creek drainage below Pear Lake.

Zinc.-The highest concentrations of zinc occur in several clusters (fig. 6). The upper reaches of Sheep Creek and the drainages around Cannivan Gulch are distinctly anomalous in relation to other parts of the study area. High values are also found in the Elkhorn Creek, David Creek, and Billings Creek drainages.

Lead.-The highest concentrations of lead (fig. 7) are in Buffalo Head and Queens Gulches, upper Boulder Creek below Black Lion Lake, the intermediate reaches of Sheep Creek, along much of Canyon Creek, Elkhorn Creek, the middle and upper reaches of David Creek, Dingley Creek, and along lower Billings Creek.

Molybdenum.-A northeasterly trending belt of high molybdenum values extends from Wellman and Dingley Creeks over the crest of the mountains to the upper reaches of Birch Creek and David Creek (fig. 8). Clusters of high values also occur in Elkhorn Creek, upper Canyon Creek, and the upper reaches of Boulder and Sheep Creeks.

Arsenic.-Anomalous in any detectable concentration, arsenic values occur in four major clusters (fig. 9). One is in the upper reaches of Sheep Creek and in the vicinity of Cannivan Gulch. A second cluster is found north of Granite Mountain and along Canyon Creek west of Hecla. A third cluster occurs in the Elkhorn CreekDavid Creek drainage area, and the fourth cluster occurs in upper Dingley and Wellman Creeks. Scattered sites where arsenic was detected are found north of Torrey Mountain and along Rattlesnake Creek.

Antimony.-Detectable antimony is most common in samples from a broad area including Sheep Creek, upper Boulder Creek below Black Lion Lake, the Cannivan Gulch area, and Canyon Creek (fig. 10). Antimony was 


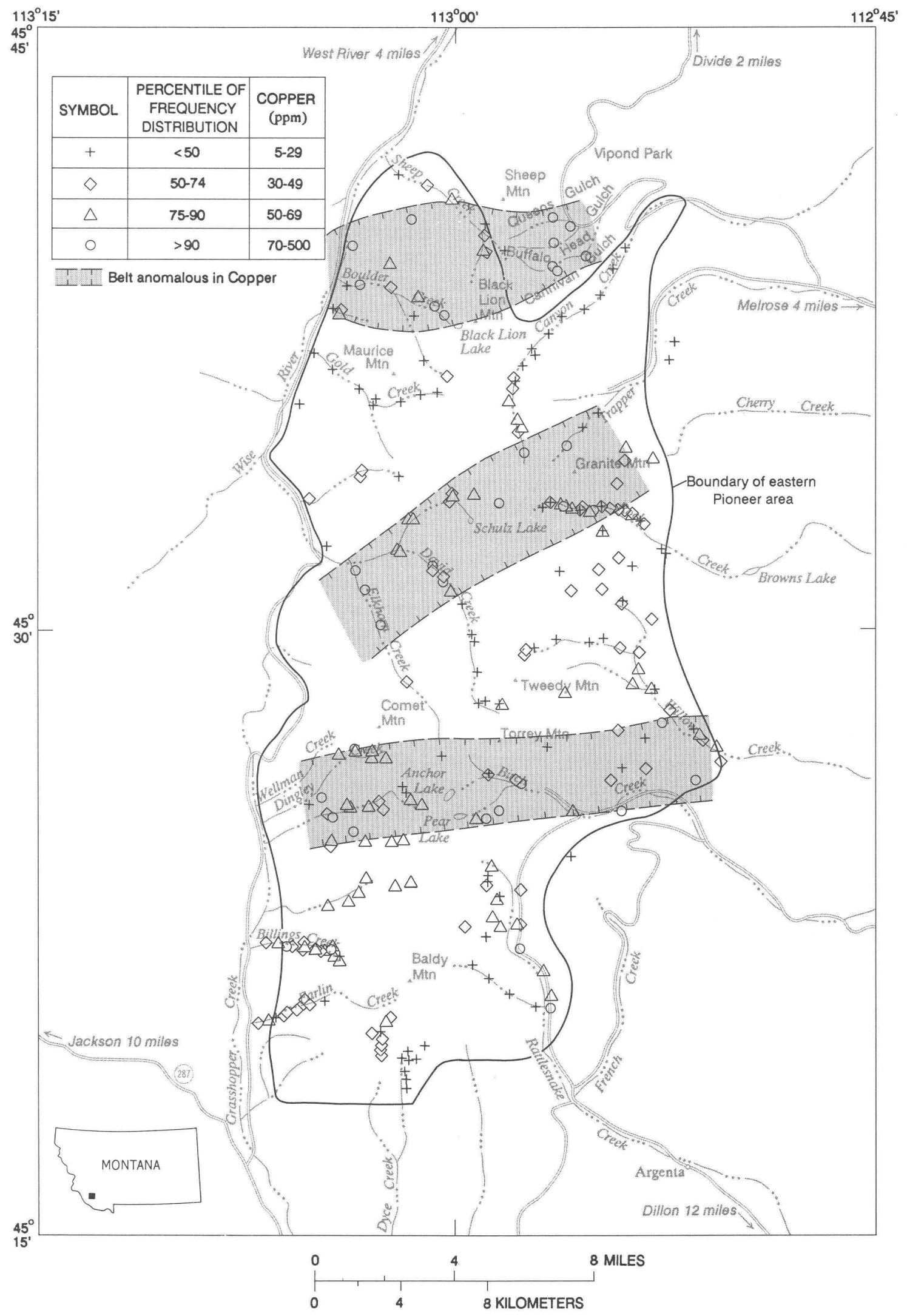

Figure 5. Distribution of copper in stream sediments. Shaded area is belt of highly anomalous samples. 


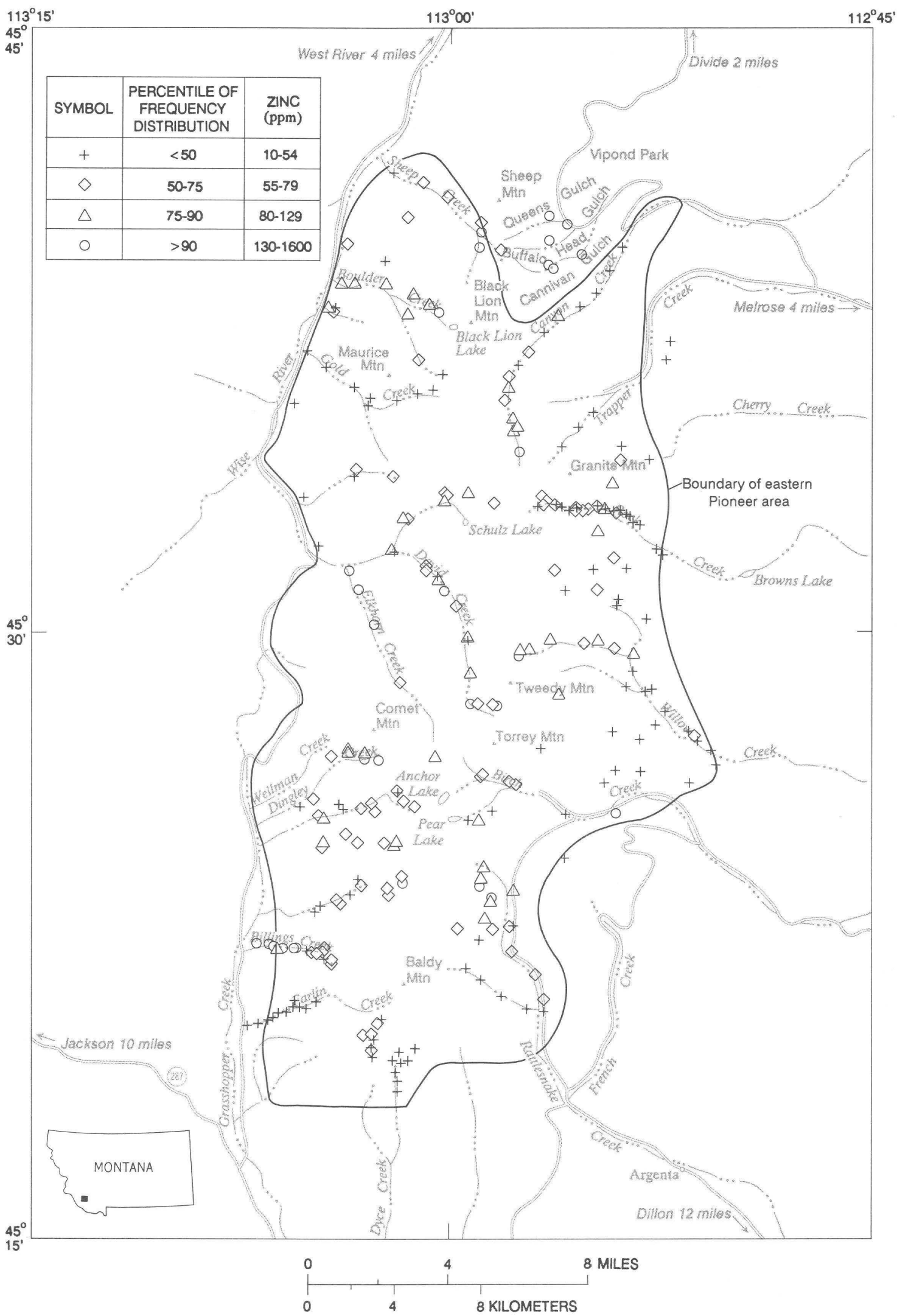

Figure 6. Distribution of zinc in stream sediments. 


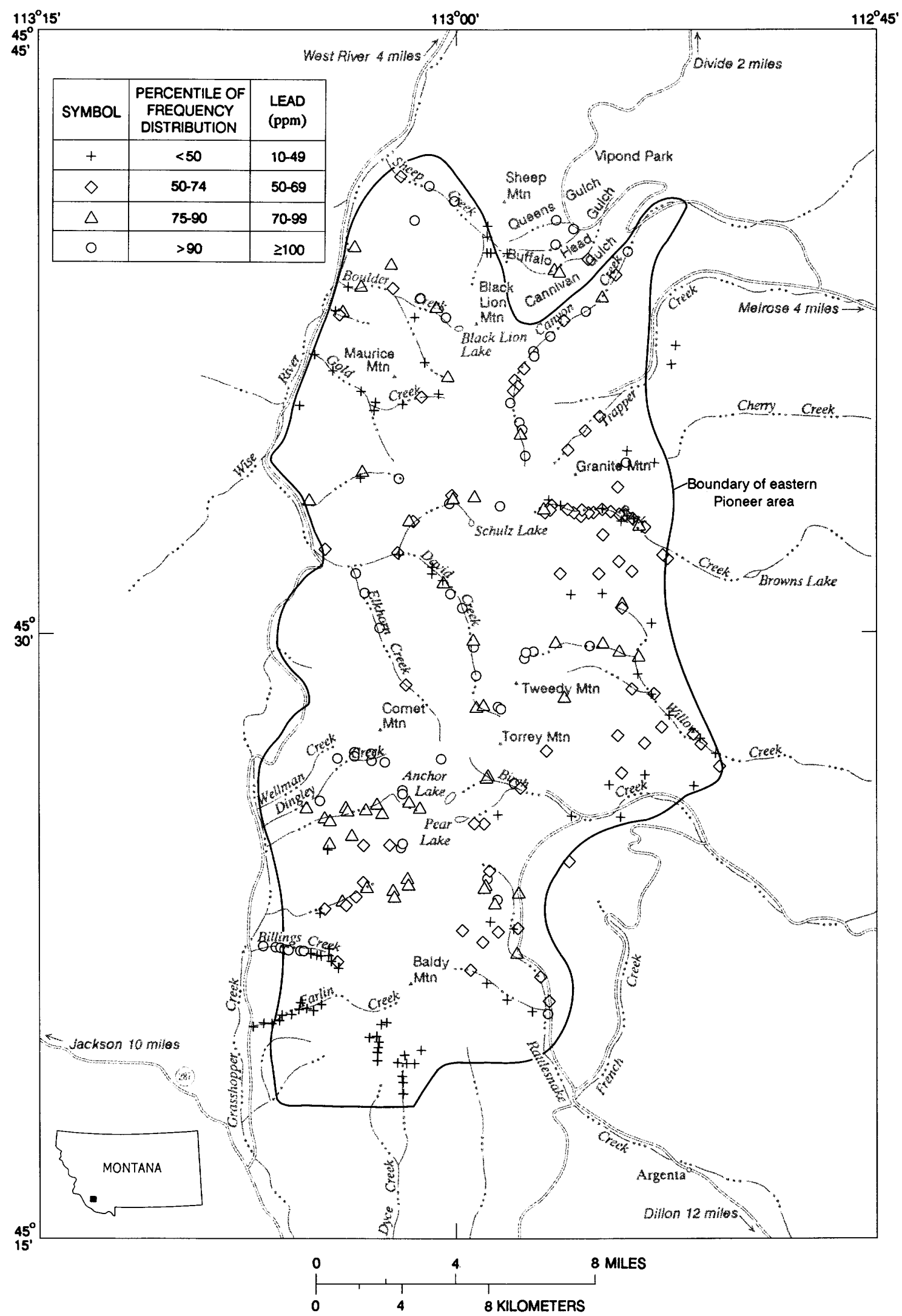

Figure 7. Distribution of lead in stream sediments. 


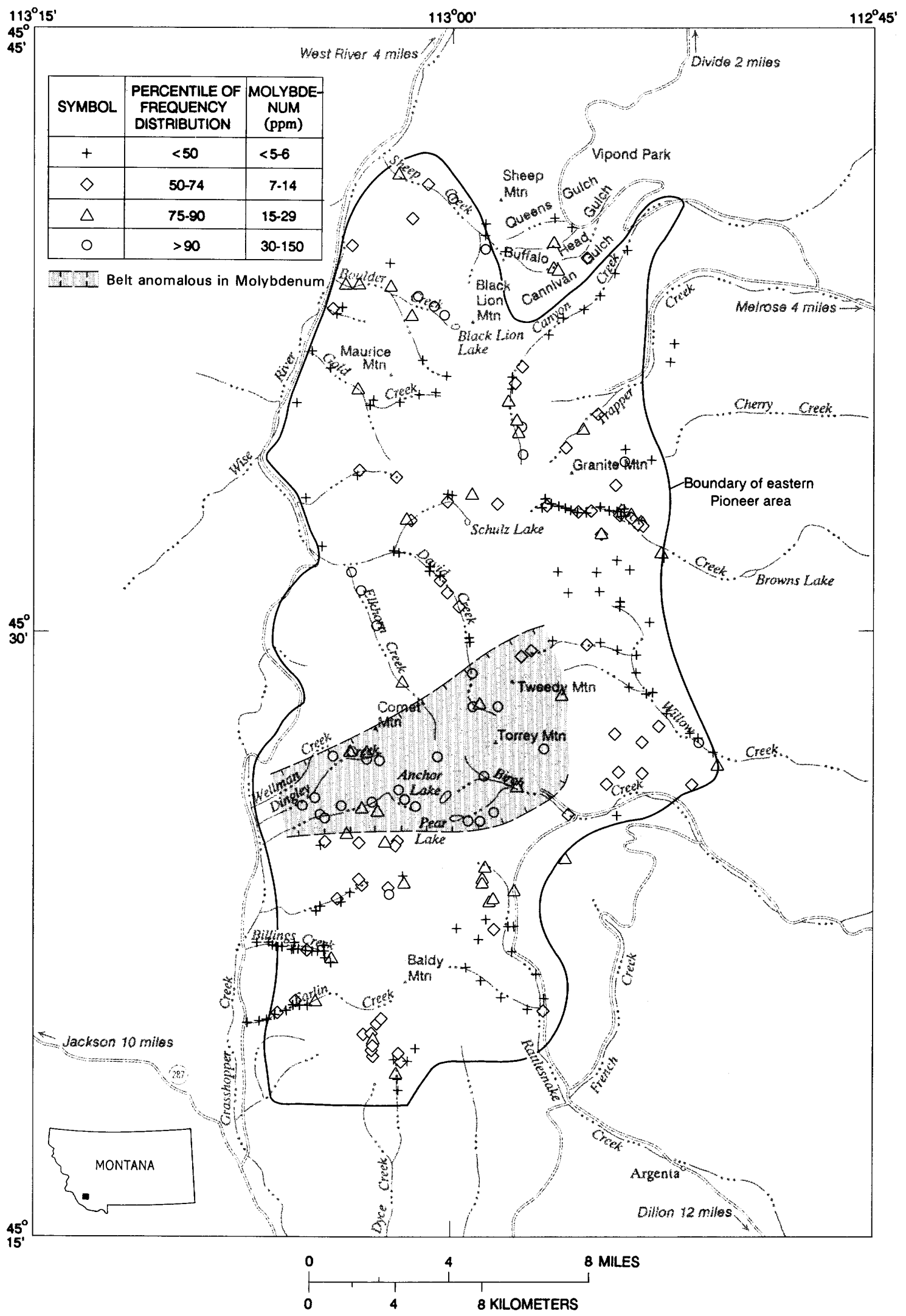

Figure 8. Distribution of molybdenum in stream sediments. Shaded area is belt of highly anomalous samples. 


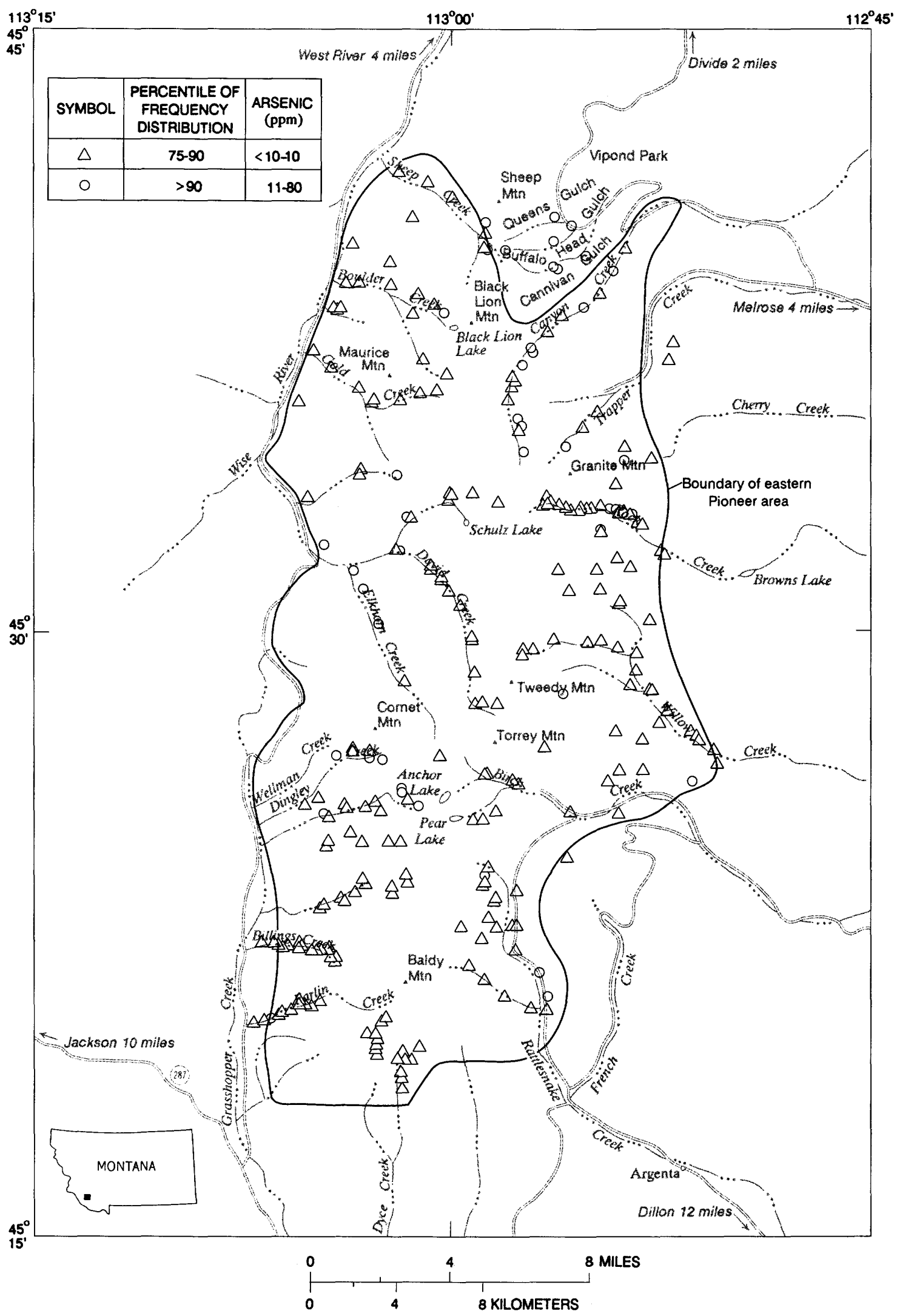

Figure 9. Distribution of arsenic in stream sediments. 


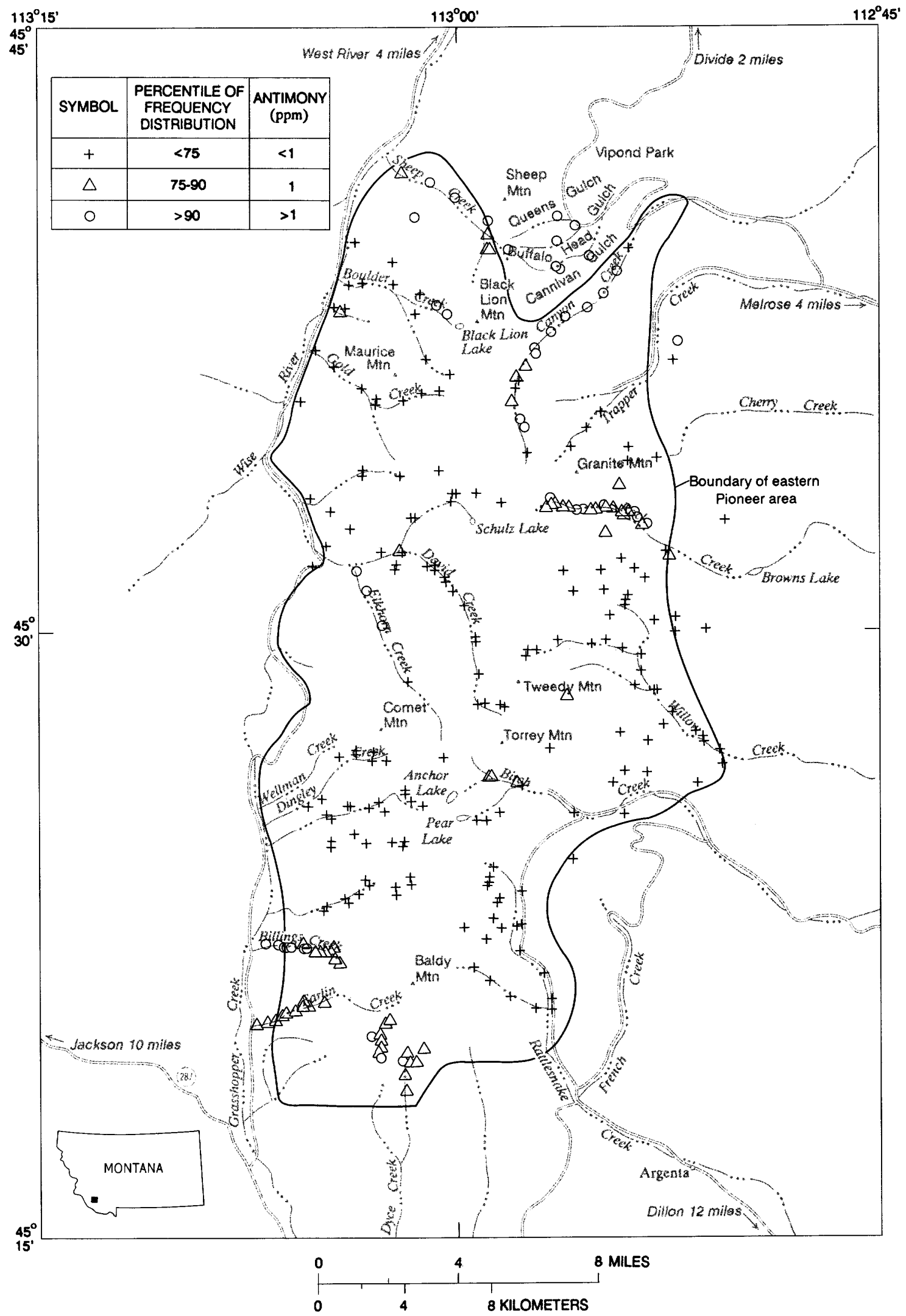

Figure 10. Distribution of antimony in stream sediments. 
also detected in Rock Creek, Elkhorn Creek, lower Billings Creek, and Dyce Creek.

\section{MINERAL RESOURCES}

\section{Setting}

The eastern Pioneer area is in a highly mineralized part of southwest Montana. Mineral production from the region, mainly of base and precious metals, is dominated by the Butte district located about $50 \mathrm{~km}$ to the northeast, where ores valued at over $\$ 6,000$ million have been mined since 1864. At least 24 other districts in the region are credited with production worth more than $\$ 5$ million each at the time of production, and several times that number of smaller districts have produced lesser amounts. In addition to base and precious metals, some districts have produced substantial amounts of tungsten and manganese. Nonmetallic minerals of importance produced nearby are phosphate rock, talc, and chlorite.

Historically, metal mining in the Pioneer Mountains followed a typical pattern by focusing first on gold in placer deposits, then on lode deposits of gold, silver, and lead; these have been the principal metals mined there. Later (1950's), tungsten became important, and, still later (1960's to 1980's) interest shifted to molybdenum. Metal mining in Montana began at Bannack in 1862 , and most of the other districts in the Pioneer Mountains (fig. 1) were discovered in the 1860's and 1870's. Their heyday was over by 1910 , although mining has continued sporadically to the present. The Bannack, Blue Wing, and Argenta districts lie to the south; Browns Lake, Lost Creek, and Birch Creek (Utopia) lie to the east; and Quartz Hill-Vipond lies to the north-all within $20 \mathrm{~km}$ of the eastern Pioneer area (fig. 1). Districts wholly or partly within the eastern Pioneer area are Hecla, Elkhorn, Polaris, and Baldy Mountain. Most of these districts produced ore from vein and replacement deposits that was valuable chiefly for gold, silver, and lead in proportions that varied from one district or mine to another. Browns Lake, Lost Creek, and Birch Creek contained skarn or contact metasomatic deposits valuable for tungsten, copper, or iron.

Discovery in 1968 of the Cannivan Gulch molybdenum deposit, which is located a mile east of the northern part of the area, resulted in the intense search for other similar deposits through the 1970's and in the discovery of several prospects (fig. 1) in the Pioneer Mountains. Exploratory drilling has been done at five of these, and at two others, at least, other exploratory work and geologic studies have been done. Four of these molybdenum prospects (fig. 12)-Black Lion, Moose Creek, Pear Lake, and the Elkhorn district-are within the eastern Pioneer area, and another (at Price and
Hot Springs Creeks) is just west of the Elkhorn district.

Exploratory drilling has been underway for several years for skarn tungsten deposits along the batholith contact between the Browns Lake and Lost Creek districts. This area is about $3 \mathbf{~ k m}$ east of the eastern Pioneer area. Tungsten in quartz veins has also been explored for by drilling in the Elkhorn district in the early 1970's; results of this drilling are proprietary.

\section{Mining Districts in the Eastern Pioneer Mountains}

Geologic knowledge and mining history of the mines and mining districts were summarized by Geach (1972), and information on some of them was given by Winchell (1914). Numerous other reports dealing with specific mines and districts include Shenon (1931), Karlstrom (1948), Pattee (1960), Goudarzi (1941), and Taylor (1942). The mining districts are briefly described below, generally in clockwise order through the eastern Pioneer Mountains; their location is shown on figure 1.

Quartz Hill-Vipond district.-This district extends from Sheep Creek at the northern tip of the study area about $15 \mathrm{~km}$ northeastward and is about $5 \mathrm{~km}$ wide. It is underlain largely by folded carbonate strata of Paleozoic age, by Black Lion Conglomerate and overlying quartzite of Paleozoic or Proterozoic age, and by a fault block of Proterozoic granitic gneiss (Zen and Dutro, 1975; Zen, 1977). The beds are deformed by folds and faults mainly of northwest trend. The mines and prospects exploited principally vein and replacement deposits in the Cambrian Hasmark Formation and to a minor extent deposits in gneiss and pebbly quartzite. The veins are in minor fractures dominantly of northeast trend. Taylor (1942) emphasized the structural control of ore deposition; the veins that occupy fractures in the Hasmark did not break across the overlying less competent Red Lion Formation, and, locally, replacement ore bodies formed outward along fold crests from the fractures immediately below the Red Lion. Nearly all production from the district was from such replacement deposits in the Lone Pine mine. Silver, the most significant commodity produced, was contained mainly in tetrahedrite and secondary minerals. Galena and sphalerite are also present in the quartz-barite gangue (Goudarzi, 1941; Geach, 1972). In addition to silver, which probably amounted to over 2,000,000 ounces, some gold, copper, lead, and zinc were produced. Geach (1972) listed production of over 1 million ounces of silver from 1902-1965, but that total did not include the Lone Pine ore body or several other ore bodies that were mined before 1900 .

As used in this report, the Quartz Hill-Vipond district includes the Cannivan Gulch molybdenum deposit described by Schmidt and Worthington (1979) and Hammitt and Schmidt (1982). 
Hecla district.-Located in the northeastern part of the eastern Pioneer area at the head of Trapper Creek, the Hecla district is the largest, in terms of past production, of any in the Pioneer Mountains. As mapped by Karlstrom (1948) and E-an Zen (unpub. mapping), the mines are in Paleozoic carbonate strata on the flanks of a dome, which is cored by Black Lion Conglomerate. The south edge of the dome is transected by the Pioneer batholith. Strata overlying the Black Lion, within the productive part of the district, are of Cambrian to Mississippian age. The deposits are veins and fracture-controlled replacement bodies in dolomite. The larger ore bodies are pods, layers, and irregular winding tubes. As the stratigraphy is currently interpreted, favorable beds are in the upper part of the Hasmark Formation, the middle of the Hasmark, and the middle of the Jefferson Dolomite. Small anticlinal crests and fractures are local controls of ore deposition. Several ore bodies are directly beneath the Red Lion Formation. Production from 1873 to 1965 had a total value of nearly $\$ 20$ million (Geach, 1972); the ore was valuable mainly for silver and lead, but copper, gold, and zinc were also derived from the ores.

Browns Lake and Lost Creek districts. - Though separated by $5 \mathrm{~km}$, these areas are each about $2 \mathrm{~km}$ east of the eastern Pioneer area, and they are similar geologically to each other. Ore is found in the Amsden Formation of Mississippian and Pennsylvanian age where it is intruded by granodiorite of the Pioneer batholith. At Browns Lake the beds dip moderately toward the batholith contact, and at Lost Creek the beds dip nearly vertically and strike parallel to the contact. Contact metamorphism has converted marly beds to skarn, limestone to marble, and shale to hornfels. Locally, the skarn contains scheelite, especially where it is rich in garnet. Although developed initially as a copper prospect, the Browns Lake mine has been important only as a tungsten producer. It was active during the 1950's when 625,107 tons of ore averaging 0.35 percent $\mathrm{WO}_{3}$ were produced (Pattee, 1960). The Lost Creek area produced 21,150 tons of ore averaging 0.18 percent $\mathrm{WO}_{3}$, also in the 1950's (Pattee, 1960).

Birch Creek (Utopia) district.-Straddling Birch Creek several kilometers south of the Lost Creek district and $5 \mathrm{~km}$ southeast of the eastern Pioneer area, the Birch Creek district is similar geologically to Browns Lake and Lost Creek. Skarn has formed in several Paleozoic formations in contact with the Pioneer batholith. The Indian Queen mine in Mississippian Mission Canyon Limestone produced copper and silver. Prospects in the Amsden Formation contain copper, molybdenum, and tungsten, and a small magnetite-skarn deposit in Cambrian dolomite has produced some iron ore, probably used as smelter flux. Ore from the Indian Queen mine was worth $\$ 244,004$, according to Geach (1972); this accounted for the bulk of the production from the district.
Argenta district.-Southeast of the eastern Pioneer area, the Argenta district is along Rattlesnake Creek and its tributaries, Ermont Gulch and French Creek. Areally, it is the largest of the eastern Pioneer districts, covering over $130 \mathrm{~km}^{2}$. The district is underlain by Middle Proterozoic and Paleozoic sedimentary rocks that have been intensely faulted and by plutonic to hypabyssal intrusive rocks of Late Cretaceous and Tertiary age. The district is centered in Paleozoic rocks on the southeast flank of a southwest-plunging anticline that contains the Middle Proterozoic Garnet Range(?) Formation of the Missoula Group in its axial part. The northwest flank of the anticline is an imbricated and overturned zone east of the Kelley thrust. The central part of the district is highly fractured by many high-angle faults of northwest and northerly trend. The largest mineral deposits are in veins and replacement deposits in Mission Canyon Limestone near intrusive contacts; other veins occupy fractures in detrital sedimentary rocks, and a few are in intrusive rocks. In the central part of the district the deposits produced mainly lead and silver. Gold was the main commodity produced in a few mines, chiefly in the Ermont mines area at the south side of the district, where ore is in Jefferson Dolomite and fine-grained granodiorite, and in the French Gulch area at the northwest edge of the district, where replacement ore bodies are in sheared and faulted Jefferson Dolomite. According to Geach (1972) production from 1902 to 1965 had a value of about $\$ 5.5$ million; earlier production was no doubt substantial, perhaps comparable to the post-1902 production, but its actual value is unknown.

Blue Wing district.-The Blue Wing district is several kilometers southwest of the Argenta district; it adjoins the Bannack district which is farther south. Mississippian limestones and fine-grained granodiorite, which has intruded the limestone, are the principal rocks exposed. A large irregular sill of the granodiorite seems to have intruded along the contact between the Mississippian rocks and tuffs of Cretaceous age. Mississippian limestone is recrystallized to white marble in a halo around the granodiorite. The deposits are chiefly vein and replacement bodies in the recrystallized limestone; some veins in the granodiorite have also been productive. The ore was valuable mainly for silver, although lead, copper, zinc, and gold were also recovered. The New Departure mine was by far the largest producer in the district. Geach (1972) estimates that the New Departure mine's production was valued at $\$ 1.5$ to $\$ 3.0$ million-possibly as much or more than the other mines in the district combined.

Bannack district.-The Bannack district straddles Grasshopper Creek valley south of the Blue Wing district. At the present level of exposure, it is seen that a small granodiorite stock intruded folded and faulted Paleozoic formations-mainly Madison Group (Mission Canyon Limestone and Lodgepole Limestone). Bannack is most 
famous for the gold placers along Grasshopper Creek. Lode deposits are in veins and fracture-related replacement deposits in Madison Group limestone near the stock. The ore bodies are localized either near the outer zone of contact metamorphism - the change from white marble to gray limestone-or near the granodioritemarble contact but beyond a selvage of skarn where skarn is present. The lode ores at Bannack were valuable chiefly for gold that was in quartz and pyrite; chalcopyrite, galena, and sphalerite are common minor constituents. The lodes may have produced a few million dollars worth of metals, but production from placer deposits exceeded that from lodes.

Baldy Mountain district.-The Baldy Mountain district, at the southwest tip of the eastern Pioneer area, is small and, in terms of production, unimportant. It is in folded and faulted Paleozoic rocks south of and adjacent to gabbro and granodiorite plutons of the Pioneer batholith. Deposits are in veins and minor replacement and contact metasomatic deposits chiefly in Cambrian and Devonian carbonate rocks. Most of the veins trend north. Modest amounts of gold, silver, copper, lead, and zinc valued at $\$ 27,479$ were mined from 1902-1965 (Geach, 1972), more was probably mined earlier. Small amounts of tungsten were mined from skarn in the 1950's (Pattee, 1960).

Polaris district.-Polaris district is north of the Baldy Mountain district on the west edge of the eastern Pioneer area. An elliptical outcrop $1 \mathrm{~km}$ wide and $4 \mathrm{~km}$ long of Paleozoic sedimentary rocks-mainly carbonate-is intruded on the east by the Pioneer batholith and is in fault contact on the north, west, and south with Middle Proterozoic quartzite and micaceous hornfels. The Paleozoic rocks are interpreted as a window in a thrust sheet of the Proterozoic quartzite. The Polaris mine is the only significant producer in the district. It is located in dolomitic marble adjacent to a short N. $60^{\circ}$ E.-trending segment of the generally north-trending fault between the marble and Proterozoic quartzite. Numerous shoots of mainly oxidized ore probably occupy tension fractures adjacent to the fault. The primary mineral was probably tetrahedrite, and the main commodity has been silver; minor gold, copper, lead, and zinc were also mined. Recorded production from 1902-1965 amounts to about $\$ 139,000$ (Geach, 1972); however, the principal production was prior to 1902 , and substantial amounts were mined after 1965.

Elkhorn district.-This district is along the west edge of the eastern Pioneer area. It is in granodiorite of the Pioneer batholith along the Comet fault, which in the district trends N. $20^{\circ} \mathrm{E}$. and dips $45^{\circ}$ west. The deposits are in small shoots in persistent quartz veins mainly in the hanging wall of the Comet fault. Many of the veins trend about N. $50^{\circ} \mathrm{E}$. and others trend east. The ore was valued mostly for silver contained in tennantite-tetrahedrite; the ores also contained pyrite, galena, sphalerite, chalcopyrite, and locally wolframite and molybdenite. The 1,000-level adit of the Elkhorn mine was driven between 1913 and 1921 to intersect the silver-bearing veins about $300 \mathrm{~m}$ below their outcrop, but very little base and precious metals were found. However, a large number of the quartz veins cut in the 1,000-level adit contain muscovite and molybdenite, suggesting that the district is favorable for molybdenum. An estimate of production from the Elkhorn district since 1872 is about $\$ 500,000$ worth of ore.

\section{Resource Assessment}

The procedure used to assess the mineral resource potential of the eastern Pioneer area is one of analogy with nearby mineralized areas described in the preceding pages. We have compared geologic, geochemical, and geophysical characteristics of likely or possible mineral deposit types with these features in the study area. Certain criteria and relationships that seem to be critical or favorable to the formation, occurrence, or recognition of each deposit type are used to make the comparison. The degree to which any geologic environment within the eastern Pioneer area contains the critical or favorable features will determine our confidence that an individual tract where the environment is present contains deposits of a particular type.

Each part of the eastern Pioneer area where the mineral potential is regarded as being significantly higher than the general region-none of which can be discounted entirely-is classified here as having high $(\mathrm{H})$, moderate (M), or low (L) mineral potential. While based on objective data, these classifications are determined by us in a subjective manner. An area determined to have high mineral potential contains most of the critical and favorable features of a particular deposit type; an area determined to have moderate mineral potential has many of these features; and an area determined to have low mineral potential has a few of these features. Most parts of the eastern Pioneer area that are not classified as having high, moderate, or low mineral potential have some unspecified mineral potential for certain deposit types.

The mineral deposit types considered to have significant potential and for which information is adequate to make an assessment are:

1. vein and replacement deposits of base and precious metals,

2. stockwork molybdenum,

3. skarn tungsten, copper, and iron,

4. phosphate,

5. placer gold,

6. stratabound copper, and

7. manganese. 
Several other deposit types important in the surrounding region were considered, but, because of the absence of essential geologic criteria within the eastern Pioneer area, no discussion of the assessment is given. Deposits in Archean crystalline rocks of talc, iron, chlorite, and other minor types, for example, are considered to have essentially no chance of being present within reach of plausible exploration or mining in the eastern Pioneer area because Archean crystalline rocks are not present in outcrop or at sufficiently shallow depth.

The mineral assessment is presented in the form of three maps (figs. 11-13) that show tracts or localities most favorable for each deposit type. Figure 14 summarizes the three maps and shows all areas of substantial mineral potential. Where an area is favorable for more than one deposit type, the levels of favorability are not considered to be additive, but rather the highest level in each area is shown.

Vein and Replacement Deposits of Base and Precious Metals

\section{Characteristics}

Known vein and replacement deposits of base and precious metals in the Pioneer Mountains owe their location to controls imposed by host rocks, by associated plutons, and by structure.

Important characteristics of host rocks are composition and brittleness. Where chemically reactive carbonate rocks have been metamorphosed to marble adjacent to plutons, both characteristics are present and have provided favorable ground for formation of the largest base- and precious-metal deposits. Stratigraphic units empirically known to be susceptible are the Hasmark and Jefferson Formations. In the Hecla and Quartz Hill-Vipond districts, these units have been the most significant hosts for replacement ore. South of the Pioneer batholith, especially around satellitic plutons, recrystallized Mission Canyon Limestone has been the most important host in the Argenta, Blue Wing, and Bannack districts. Other carbonate-bearing formations, such as Amsden, Phosphoria, and Kootenai, have almost no vein or replacement deposits (other than skarn) in them-perhaps because fortuitously they were not favorably situated in most places with respect to plutons or other sources of mineralizing fluids. Noncarbonate brittle rocks that contain veins are plutonic intrusive rocks and detrital sedimentary rocks, particularly those of Middle Proterozoic and Cambrian age; these have been important hosts for veins in the Argenta and Elkhorn districts.

A close association of vein and replacement deposits with plutons is typical of the mining districts in the eastern Pioneer Mountains, although some districts show this relationship more closely than others. The association is very close and obvious for Bannack, Blue Wing, Argenta, and Elkhorn and less so or uncertain for Hecla, Quartz Hill-Vipond, Baldy Mountain, and Polaris. Smaller plutons seem more favorable than the major batholith plutons, perhaps because of pressure and temperature factors. Elkhorn is the only district within the batholith proper, and it probably is associated with a slightly younger intrusive pulse, perhaps the quartz porphyry, which is in numerous small bodies nearby.

A fracture control of most of the vein and replacement deposits can be demonstrated. Some of the fractures, as in the limestones at Bannack and Argenta, extend very short distances, some less than $300 \mathrm{~m}$, outward from the plutons; others are mineralized faults up to several kilometers long with minor offset, such as at the Goldfinch Group of claims, Argenta district; and still others are associated with major through-going structures such as the Comet fault in the Elkhorn district, where numerous subsidiary fractures in its walls are mineralized. Many replacement deposits are fracture controlled; they tend to emanate from quartz veins. Replacement deposits in axial parts of anticlines in the Quartz HillVipond district are in Hasmark Formation associated with steep quartz veins and directly beneath a capping of incompetent shaly Red Lion Formation. According to Taylor (1942), the fractures that were open in the Hasmark did not penetrate the Red Lion, which, in effect, dammed ascending mineralizing fluids and promoted replacement along bedding. This control was local because in many places higher stratigraphic units were mineralized.

Stream-sediment samples collected from streams draining known mineralized areas in the eastern Pioneer Mountains contain anomalous amounts of silver, arsenic, antimony, zinc, lead, molybdenum, and' copper.

Geophysical anomalies directly associated with vein and replacement deposits are generally too small to be detected with the reconnaissance aeromagnetic and gravity data available for the eastern Pioneer Mountains. An aeromagnetic low along the Comet fault suggests hydrothermally altered rock beneath the Elkhorn district. This alteration may be an aspect of the vein mineralization. The northwestward-plunging aeromagnetic high beneath the Hecla district indicates either a plunging bulge in the batholith contact or a separate pluton at depth. Pronounced magnetic highs coincide with the Argenta and Bannack districts but not with the Blue Wing.

Resource Assessment

Eight areas (fig. 11) have significant potential for vein and replacement deposits.

1. Sheep Creek-Clifford Creek.-This area has many characteristics of productive mining districts in the 


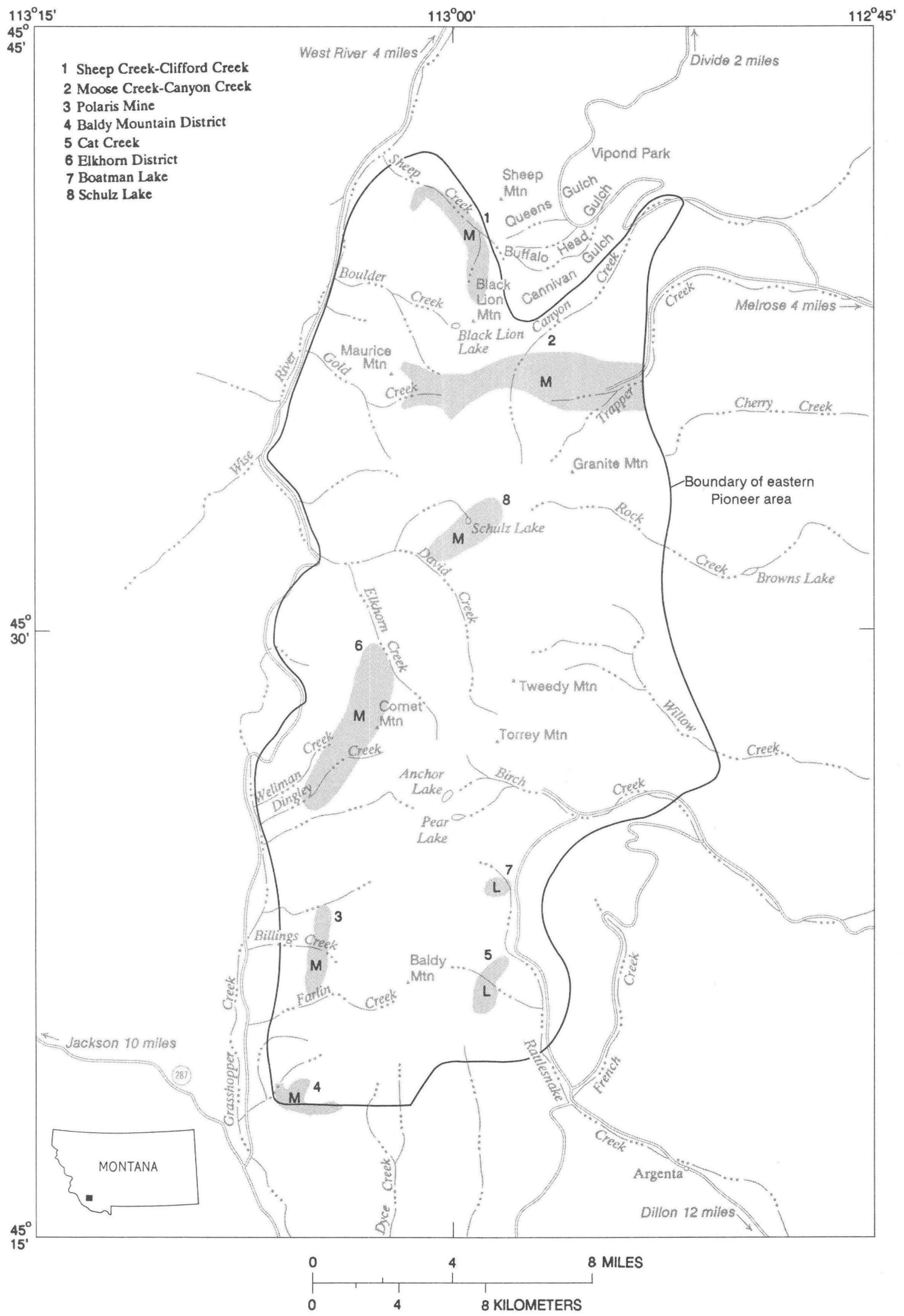

Figure 11. Mineral potential map-vein and replacement deposits of base and precious metals. $M$, area of moderate potential; L, area of low potential. 
Pioneer Mountains, specifically favorable host rocks adjacent to a granite stock. The rocks at the contact are mainly Jefferson Dolomite and Hasmark Formation; a small area of outcrop of hornfelsed Red Lion Formation near the Blue Bell mine in the Quartz Hill-Vipond district suggests that it too may be in contact with the granite beneath a cover of glacial moraine. The favorable zone adjacent to the contact of the granite is largely covered by a lateral moraine of the Sheep Creek glacier. The carbonate rocks are mineralized at the Blue Bell mine and the Atlas prospect, both described by Geach (1972). The Atlas is in a slice of recrystallized, locally bleached Jefferson Dolomite about $500 \mathrm{~m}$ wide between the stock and the inferred Fourth of July fault. Malachite-stained vein quartz and galena were found on the dump of the adit, which is caved at the portal. The Blue Bell consists of vein or replacement deposits explored by pits and shallow shafts adjacent to Sheep Creek. Gray dolomite and partially oxidized galena in a quartz gangue are on the dumps.

Stream-sediment samples from Sheep Creek and Clifford Creek and rock-chip samples from the dumps of the Atlas and Blue Bell mines are anomalous in several metals commonly associated with vein and replacement deposits. A sample from the Atlas dump contained 150 ppm silver, 1,200 ppm arsenic, $100 \mathrm{ppm}$ bismuth, $50 \mathrm{ppm}$ cadmium, 7,000 ppm copper, 2,000 ppm lead, $>200 \mathrm{ppm}$ antimony, and $>2,000 \mathrm{ppm}$ zinc. A sample from the Blue Bell mine contained $70 \mathrm{ppm}$ silver, $20 \mathrm{ppm}$ cadmium, 300 ppm copper, 1.5 percent lead, $10 \mathrm{ppm}$ bismuth, $10 \mathrm{ppm}$ arsenic, $40 \mathrm{ppm}$ antimony, $10 \mathrm{ppm}$ tin, and $130 \mathrm{ppm}$ zinc.

The aeromagnetic data indicate that the stock is more magnetic than the wall rocks. The steep magnetic gradient, especially on the east side of the stock, indicates that the stock is steep sided. A low on the north side is a combination of topographic effect, a dipolar low, and the difference in magnetization between the granite and the carbonate wall rocks.

The Sheep Creek-Clifford Creek area has moderate potential for vein and replacement deposits of base and precious metals.

2. Moose Creek-Canyon Creek.-A belt about 1.5 to $3 \mathrm{~km}$ wide that consists largely of favorable carbonate rocks extends west from the Hecla district across the north boundary of the Pioneer batholith. In the headwaters of Boulder and Moose Creeks, the belt is between the batholith and the Clifford Creek stock and the rocks have been contact metamorphosed by both. At its western edge the carbonate rocks have been overridden by a thrust fault, which dips about $20^{\circ}$ west; thus, the favorable beds are buried progressively deeper to the west, and they also become progressively farther from both plutons. Movement along the Fourth of July fault has dropped the thrust fault and the favorable carbonate beds west of the fault perhaps more than $700 \mathrm{~m}$, which places them beyond consideration at this time as hosts for discoverable or recoverable resources. Favorable units in this belt are the Hasmark and Jefferson Formations. The formations are deformed into numerous folds; the Hasmark immediately beneath the Red Lion Formation is particularly favorable in the axes of plunging anticlines.

No mines and few prospects are in this belt. Several prospects are on the west flank of Lion Mountain on the west edge of the Hecla district. Although the deeper of the Lion Mountain mines in the Hecla district came within a few hundred feet of resurfacing on the west flank of Lion Mountain, little evidence for mineralization at the surface in this area has been found. The Joe Maurice mine is north of Gold Creek near its head. It is in Hasmark Formation in the core of a tightly compressed anticline and consists of several small scattered prospect workings. The only evidence of mineralization is minor amounts of secondary copper minerals found on dumps. No production is known. A geochemical sample from a dump contains: $500 \mathrm{ppm}$ silver, $200 \mathrm{ppm}$ arsenic, $70 \mathrm{ppm}$ cadmium, $3,000 \mathrm{ppm}$ copper, $700 \mathrm{ppm}$ lead, $>200 \mathrm{ppm}$ antimony, and $480 \mathrm{ppm}$ zinc. Scattered stream-sediment samples from Canyon Creek are also anomalous in several metals. The valleys of Canyon Creek, Gold Creek, Boulder Creek, and probably Moose Creek have been glaciated and as a result are fairly well to very well exposed. If lodes were exposed at the surface, they should have been found. Nevertheless, the area has many highly favorable geologic criteria and is considered to have moderate potential for vein and replacement deposits.

3. Polaris mine window.-The Polaris mine window is a faulted block of Paleozoic sedimentary rocks intruded by the Pioneer batholith on its southwest edge. The complex structure and the metamorphism of these rocks has thus far prevented the satisfactory deciphering of the stratigraphy in most of the window. At the south end of the window, however, massive light-gray recrystallized limestone is probably Mission Canyon Limestone. The rest of the window is chiefly dolomitic marble that may be Jefferson Dolomite or Hasmark Formation. The highly productive Polaris mine is along a short N. $60^{\circ}$ E.-trending fault at the west edge of the window, where the carbonate rocks are in fault contact with Middle Proterozoic quartzite. Although the fault contact is locally steep, as at the Polaris mine, indications at the north end of the window are that the quartzite has been thrust over the Paleozoic rocks, and at the south end the Paleozoic rocks have been thrust over quartzite. Numerous other prospect diggings and small mines, such as the Silver King south of the Polaris, give indications of widespread mineralization. Samples of ore from the Polaris mine are anomalous in silver, arsenic, cadmium, copper, molybdenum, lead, antimony, zinc, and mercury. The Polaris mine window is given a moderate potential for vein and replacement deposits. 
4. Baldy Mountain mining district.-The northern part of this district is along the southwest edge of the eastern Pioneer area. The district contains favorable Paleozoic carbonate rocks that are variably fractured, folded, and intruded by various phases of the Pioneer batholith. Most of the prospects and small mines are described by Geach (1972), and other information has been supplied by D. R. Zimbelman (written commun., 1981). In the northwest part of the district-between Driscoll and Steel Creeks-the Jefferson Dolomitelocally overlain by a thrust plate of Proterozoic quartzite-is bleached and locally brecciated and mineralized. The dolomite has been replaced by finegrained quartz that is in part localized along high-angle faults. Much of the quartz forms a boxwork, presumably as a result of the complete weathering away of sulfide minerals or dolomite. Such quartz is geochemically anomalous in gold, silver, arsenic, antimony, molybdenum, tungsten, barium, and beryllium. The carbonate rocks that form a belt about $2 \mathrm{~km}$ wide along the south edge of the study area are mainly Jefferson Dolomite and strata of probable Cambrian age. Massive recrystallized limestone on the east end of the belt may be Mission Canyon Limestone. All these strata are folded, faulted, and recrystallized and contain some evidence of mineralization at numerous prospects.

This belt of rocks along the edge of the area has moderate resource potential for vein and replacement deposits. The Driscoll Creek area is the more highly anomalous geochemically and may have a higher potential than the remainder of the area.

5. Cat Creek.-An area that is largely covered by glacial moraine at the southeast boundary of the eastern Pioneer area is inferred, on the basis of a few scattered outcrops, to be underlain by lower Paleozoic strata including Cambrian carbonate rocks and Jefferson Dolomite in contact with a granodiorite pluton of the Pioneer batholith. The fact that no evidence exists of prospecting, of visible evidence of mineralization, or of significant geochemical anomalies suggests that mineralization was not widespread. Nevertheless, the geological favorability of the area requires that it be afforded at least a low measure of favorability for vein and replacement deposits.

6. Elkhorn mining district.-This district produced ore valuable for base and precious metals-mainly silver-from quartz veins in granite. Most productive veins are east- to northeast-trending structures in the hanging wall of the west-dipping Comet fault. Most exploration has been done in the northern part of the district southwest of Elkhorn Creek, where numerous veins that had been mined in the early days were consolidated and worked as the Elkhorn mine to depths of at least $100 \mathrm{~m}$ below their outcrop. The 1,000-level adit, which was a crosscut designed to intersect the veins about $300 \mathrm{~m}$ below their outcrop, cut a great many quartz veins but disclosed that the silver minerals had generally disappeared above that level, and molybdenum had become more abundant. Thus, the base- and precious-metal potential of the Elkhorn district is considered to be adequately explored in the northern part and to be probably restricted to the upper few hundred feet in the southern part. If the hanging wall block of the Comet fault has dropped more or less down dip since the time of mineralization, as Geach (1972) suggests, any comparable mineralized terrain that may have existed in the footwall block has probably been eroded. Only a few veins have been mined in the footwall.

Geochemical data on samples from Dingley Creek, which mainly reflected a source in the footwall of the Comet fault, are highly anomalous in lead and moderately anomalous in silver, molybdenum, and copper. An aeromagnetic low that coincides with the Comet fault is interpreted as being caused by hydrothermal alteration. Silicification is especially noteworthy along the inferred southward extension of Comet fault east of Wellman Creek in an area that is largely covered by moraine.

These characteristics indicate that the Elkhorn district has moderate potential for resources of base and precious metals in veins.

7. Boatman Lake.-A few prospect pits have been dug on pyritic quartz veins in an area partly covered by patented mining claims. Also present in the area are a body, probably over $30 \mathrm{~m}$ in diameter, of bleached and altered granodiorite and a rhyolite dike (Snee, 1978). Considered together, these features suggest that the area has a low potential for vein deposits.

8. Schulz Lake.-An east-northeast-trending quartz vein west of Schulz Lake has been explored by an adit at least several tens of feet long. The vein is one of several, generally smaller, veins in a weak zone of northeast-trending veins that cut granodiorite of the Pioneer batholith. Galena, sphalerite, and pyrite were found on the dump. A geochemical sample that contains ore minerals contains $1,000 \mathrm{ppm}$ silver, $1,000 \mathrm{ppm}$ arsenic, $100 \mathrm{ppm}$ cadmium, 1 percent copper, $15 \mathrm{ppm}$ molybdenum, 2 percent lead, 1 percent antimony, 1 percent zinc, and 1,000 ppm barium. The general area of the Schulz Lake prospect is considered to have moderate potential for base- and precious-metal resources in veins, although the size of this type of deposit would probably be small.

\section{Stockwork Molybdenum Deposits}

Characteristics

Most molybdenum occurrences in the Pioneer Mountains are intersecting networks or stockworks of quartz veins or are closely spaced quartz veins that are 
more or less parallel; a third, and less common type, is a coarsely crystalline vuggy greisenlike rock. Several of the occurrences are within or adjacent to granitic plutons that are probably genetically associated with the molybdenum mineralization, but others are in older country rock, either plutonic or sedimentary.

The Cannivan Gulch deposit-the only one of these numerous occurrences to be explored sufficiently to delineate a large deposit-is exposed at the surface about a mile east of the northern part of the eastern Pioneer area (fig. 1). This deposit is associated with a small compound stock of granodiorite and monzogranite that intruded Paleozoic strata of Cambrian and Devonian age. The deposit is partly within a part of the stock that consists of two phases and partly within adjacent silicated carbonate rock (Hammitt and Schmidt, 1982). Molybdenite is mostly confined to quartz veins. Alteration of the intrusive rocks has produced locally pervasive potassium-feldspar and halos of potassium-feldspar and muscovite around the veins; the veins contain quartz, pyrite, muscovite, and potassium-feldspár as well as molybdenite. Veins in the silicated carbonate rocks contain quartz, pyrite, magnetite, chlorite, and serpentine, in various combinations and locally potassium-feldspar, epidote, and (or) fluorite. The magnetite in these veins presumably accounts for the aeromagnetic high over the Cannivan Gulch deposit.

Molybdenum prospects in the western Pioneer Mountains are quartz-vein stockworks or silicified breccias; they are all in Proterozoic quartzite. Although plutons are not more than $2 \mathrm{~km}$ from these prospects at the surface, a closely associated pluton-one that may have genetic affinities-is not exposed. A single small altered silicic dike is present at two of the prospects and a pluton has been penetrated by drilling at a third.

The Price Creek and Hot Springs Creek altered zones (Pearson and Berger, 1980) are not typical of the stockwork deposits. These areas, located about 1-2 km west of the Elkhorn district, consist of greisenlike coarsegrained vuggy aggregates of quartz, muscovite, pyrite, potassium-feldspar, and minor rutile that are the result of pervasive alteration of the plutonic rocks. They are within the Upper Cretaceous Uphill Creek Granodiorite and spatially associated with quartz porphyry dikes, both of which are mineralized. Both altered zones have been explored by drilling, one in 1981, the other in 1982.

\section{Resource Assessment}

Seven areas (fig. 12) within the eastern Pioneer area have sufficient similarities to Cannivan Gulch or to other significant molybdenum prospects in the region to be considered to have potential for molybdenum resources.

1. Black Lion.-An important molybdenum prospect west of Black Lion Lake is about $5 \mathrm{~km}$ southwest of the Cannivan Gulch deposit. On the basis of information from exposed geology, surface geochemistry, and aeromagnetics, Black Lion is considered to be probably the most significant area of mineral potential in the eastern Pioneer area. The prospect consists of a cluster of closely spaced molybdenite-bearing quartz veins in a large altered zone within the southeastern part of a granite stock (Upper Cretaceous or Paleocene Clifford Creek Granite). The altered zone is limonite-stained from weathering of pyrite and contains widespread muscovite. The abundant quartz veins consist of quartz, pyrite, muscovite, molybdenite, and locally magnetite. The veins trend northerly to northeasterly. Stream-sediment samples from Boulder Creek are anomalous in molybdenum, copper, and silver, and rock samples are anomalous in molybdenum. Aeromagnetically, the Black Lion area is characterized by a low over the same granite that elsewhere produces magnetic highs; the magnetite in veins is evidently too sparse to show as a magnetic high. The low is believed to be caused by the hydrothermally altered rocks. We rate the area as having a high potential for molybdenum resources.

2. Elkhorn district.-Discussed previously for its potential for base- and precious-metal veins, the Elkhorn district has attracted attention in the last few years as a molybdenum prospect. On the lowest level (the 1,000 level) of the Elkhorn mine, at the north end of the district, numerous quartz veins contain muscovite and molybdenite. Although molybdenite is present in veins at the surface also, it seems to be much more abundant at depth. The silver, base-metal, and tungsten minerals that were mined nearer the surface apparently decreased with depth. This apparent mineral zoning does not, however, take into consideration effects of faulting, which are not well known. The west-dipping Comet fault is inferred to pass between the mined veins near the surface and the molybdenite-bearing veins exposed on the 1,000 level. If so, the apparent zoning is complicated by probable postore movement on the Comet fault. The vein density, as exposed in the 1,000-level adit, is approximately one vein per $3 \mathrm{~m}$ of adit length in the first $600 \mathrm{~m}$. The veins average several centimeters in width and range to $0.3 \mathrm{~m}$ or so. About half the veins exposed contain visible molybdenite. Thus, the molybdenite-bearing veins exposed in the adit are not sufficiently abundant to constitute an ore body. They do indicate, however, the existence of a large mineralizing system that could have produced a significant deposit somewhere beneath the Elkhorn district. If the silver-, base-metal-, and tungstenbearing veins represent near-surface manifestations of molybdenum mineralization, the entire Elkhorn district on both sides of the Comet fault must be considered favorable for significant deposits. The district is rated as having high potential for molybdenum resources. 


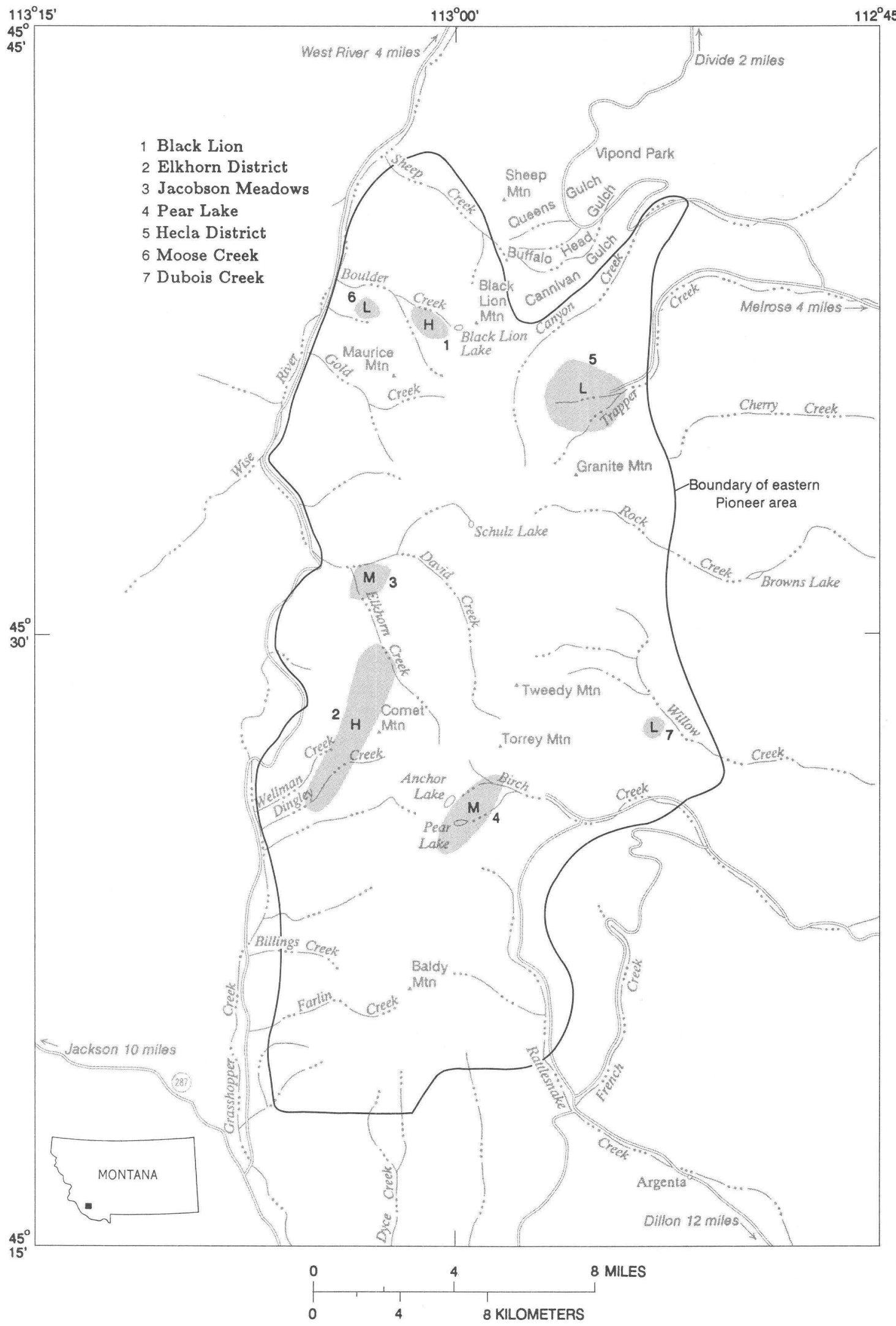

Figure 12. Mineral potential map-molybdenum stockwork deposits. $H$, area of high potential; $M$, area of moderate potential; L, area of low potential. 
3. Jacobson Meadows.-An area of hydrothermally altered granitic rocks at the confluence of Elkhorn and Jacobson Creeks contains minor amounts of molybdenite in quartz veins. The area is described further by Pearson and Berger (1980).

The altered zone is a triangular area about $1.5 \mathrm{~km}$ on a side. It is in granodiorite and quartz porphyry of the Pioneer batholith adjacent to the probable extension of the Comet fault northward from the Elkhorn district. The quartz porphyry is in dikes and irregular small bodies cutting granodiorite, although individual bodies have not been delimited.

The altered rocks contain disseminated pyrite in fresh-appearing rocks. They are cut by intersecting quartz veinlets that also contain pyrite, magnetite, muscovite, biotite, chlorite, potassium-feldspar, and rutile in various proportions and combinations. Molybdenite was found at several places in quartz-pyrite veins.

Geochemically, rock and stream-sediment samples from the area are anomalous for arsenic, silver, lead, zinc, copper, and molybdenum. Silver and zinc are the most frequent associates with molybdenum in mineralized rock samples.

The altered area lies along the magnetic low that marks the Comet fault. The Jacobsen Meadows altered zone has moderate potential for molybdenum resources.

4. Pear Lake.-Molybdenite in the Pear LakeAnchor Lake area was first described as the Monaghan prospect (Kirkemo and others, 1965) and was investigated in more detail by Willis (1978). A large block of claims was staked about 1978 although no evidence of exploratory work was seen. Molybdenite is present in northeast-trending greisenlike veins and pockets and in quartz veins that form a northeast-trending belt that cuts granodiorite and quartz porphyry of the Pioneer batholith. A propylitically altered breccia pipe is near the crest of the range west of Pear Lake. Chalcopyrite, galena, and sphalerite are also sporadic constituents of the veins. Samples of mineralized rock from near Anchor Lake contain up to $2 \mathrm{ppm}$ silver, $200 \mathrm{ppm}$ copper, 2,000 ppm molybdenum, $100 \mathrm{ppm}$ lead, $15 \mathrm{ppm}$ antimony, $50 \mathrm{ppm}$ tungsten, $20 \mathrm{ppm}$ tin, and $280 \mathrm{ppm}$ zinc. The area has potential resources of molybdenum, and the propylitically altered breccia pipe in particular suggests the possibility of deep-seated mineralization. The Pear Lake area has moderate potential for molybdenum resources.

5. Hecla district.-If vertical mineral zoning were to exist in the Hecla district, similar to that discussed previously for the Elkhorn district, the silver- and leadrich ores conceivably could give way downward to molybdenum deposits, although evidence for molybdenum mineralization is very scarse at Hecla. Geochemical samples contain up to $20 \mathrm{ppm}$ molybdenum, and molybdenite has been reported from the district. The major mines in the district are about 1 to $2 \mathrm{~km}$ from the surface contact of the batholith and about $1 \mathrm{~km}$ from small satellitic plutons. Evidence, which does not exist at this time, for a cupola of a pluton beneath the district would increase the probability of buried deposits. Thus, the Hecla district is given a low potential for molybdenum resources.

6. Moose Creek.-An area underlain by Middle Proterozoic quartzite about $3 \mathrm{~km}$ west of the Black Lion prospect has evidence of a quartz-vein stockwork. The area is located on the ridge between Moose and Boulder Creeks. It is separated from the granite stock to the east by the Fourth of July fault, which here is inferred beneath thick soil. The only outcrop in the area is on the 7,570-ft knob; elsewhere sparse float of quartzite is the only indication of bedrock in an area of thick soil. The quartzite in the one outcrop and virtually every piece of float on the ridge is seamed by quartz veinlets, most of which contain minor limonite. Float of a porous greisenlike phase of the granite is present east of the Fourth of July fault. One sample of quartz-veined quartzite that was analyzed did not contain metals in anomalous amounts, and stream-sediment samples from Moose and Boulder Creeks on either side of the occurrence were not collected to reflect specifically a source of sediment from this area and hence were not useful. The aeromagnetic data show a westward-plunging nose that seems continuous with the magnetic high over the granite stock to the east. The area has apparently not been prospected. The quartz-vein stockwork and its location adjacent to the Clifford Creek Granite are sufficient evidence te rate the area as having low resource potential for molybdenum.

7. Dubois Creek.-A body of intrusion breccia in the east part of the eastern Pioneer area was described by Snee (1978). The breccia is composed of fragments of several phases of intrusive rocks-some of hypabyssal aspect and most more silicic than the surrounding granodiorite. The groundmass of the breccia is small in volume and appears to be igneous. Evidence of mineralization is slight: some fine-grained quartz is present, and limonite-presumably after pyrite-is minor. Eight analyzed samples of the slightly mineralized rock contain up to $150 \mathrm{ppm}$ copper, $150 \mathrm{ppm}$ molybdenum, $150 \mathrm{ppm}$ lead, $50 \mathrm{ppm}$ tungsten, and $20 \mathrm{ppm}$ tin. An aeromagnetic low coincides with the breccia body indicating a contrast in magnetization from that of the surrounding granodiorite. Glacial moraine covers the north and south margins of the breccia. The breccia body is considered to have low potential for molybdenum resources.

\section{Tungsten, Copper, and Iron Skarn Deposits}

\section{Characteristics}

Skarn deposits in the Pioneer mountains have been mined for tungsten, copper, and iron. Tungsten has been 
the most important, having been produced from three substantial deposits and at least one very small deposit. Other tungsten occurrences are known also. Coppersulfide minerals are present in most occurrences of skarn, including the tungsten-bearing ores but are known to have been mined from only one sizable deposit. Magnetite skarn was also mined from one small deposit-probably not as a source of iron ore but rather of smelter flux. The Browns Lake and Calvert mines produced most of the tungsten that has come from the Pioneer Mountains; the Lost Creek mine produced a much smaller amount, and the Garrett Hill deposit was a very small producer. The principal copper mine in skarn is the Indian Queen in the Birch Creek (Utopia) district; silver was also a significant product from the Indian Queen ore. The magnetite deposit is also in the Birch Creek district. Exploration in recent years in the Sugarloaf Mountain area between the Browns Lake and Lost Creek deposits has reportedly resulted in the discovery of significant new tungsten resources.

The skarn deposits formed in carbonate rocks at their contact with plutons of intermediate composition. The Browns Lake, Lost Creek, and Calvert deposits are in the Amsden Formation, and most other tungsten occurrences are in the Amsden; certain marl beds produced the tungsten-bearing skarn. The formation that hosts the Garrett Hill deposit is uncertain but is tentatively considered to be the Mission Canyon Limestone (D. R. Zimbelman, written commun., 1981). The Mission Canyon also hosts the Indian Queen copper deposit. The magnetite deposit is in Cambrian dolomite (Myers, 1952). The plutonic rock that is associated with most tungsten occurrences in the eastern Pioneer Mountains is the Uphill Creek Granodiorite that forms the largest pluton in the batholith. Typically, it is medium-grained, megacrystic, hornblende-biotite granodiorite.

Mineralogically, the tungsten is in scheelite that is generally in garnet-rich skarn; locally, the scheelite is associated with the darker brown (more iron-rich) garnet.

Formation of skarn deposits is favored by certain structural relations between the pluton and sedimentary host (Elliott, 1982). A dip of bedding in the sedimentary rocks toward the pluton contact is considered more favorable than horizontal beds, vertical beds, or a dip away from the pluton. Irregularities in the pluton contacts, particularly if the pluton discordantly overlies favorable beds, are also favorable; discordant apophyses may produce these favorable relationships. Fracturing of the host rocks is also favorable.

The Amsden Formation is clearly the most favorable unit for development of tungsten skarn in the Pioneer Mountains. Other carbonate formations, however, cannot be discounted.

Resource Assessmerit

Within the eastern Pioneer area, the Amsden
Formation is known only where it crosses the ridge between Canyon and Trapper Creeks (fig. 13). It does not crop out at a pluton contact within the area, nor is it inferred to be present at depth in such an arrangement.

All other contacts of carbonate formations with intermediate plutons have low potential for tungsten, copper, or iron resources in skarn (fig. 13). By analogy with nearby areas, rocks of Cambrian and Mississippian age are the more favorable. Most such contacts that are exposed are not silicated and, hence, are unlikely hosts for skarn deposits at the surface but they could be present at depth if conducive structural and stratigraphic relations exist.

\section{Placer Gold}

The first mineral deposits discovered in the eastern Pioneer Mountains were of placer gold. At Bannack (fig. 1), the stream gravels and adjacent terrace gravels along Grasshopper Creek produced perhaps as much as 387,000 oz from 1862 to 1905 (Shenon, 1931). Minor placer mining has also been done along Rattlesnake Creek at Argenta; in Fryingpan Basin, east of the Argenta mining district; along French Creek and Watson Gulch, tributaries of Rattlesnake Creek upstream from Argenta; and along Dyce Creek in the Baldy Mountain mining district. Geach (1972, p. 168) mentions production of placer gold from the Polaris district, perhaps from Billings Creek, and the Hecla (Bryant) district, perhaps Trapper Creek or its tributaries. No evidence of placering was seen in the Polaris or Hecla areas, and any placer production there can be assumed to be small. All other valleys in the eastern Pioneer Mountains were undoubtedly tested by the early prospectors, presumably without encouraging results.

Factors important in the formation of placer gold deposits are a lode source and a deposit of gravel that formed in a manner conducive to the concentration of the detrital gold particles. A lode source for the known placers in the eastern Pioneer Mountains can be identified with considerable certainty, as in the Bannack and Argenta districts, and no other significant lodes are known that might be expected to have contributed to undiscovered placers. Another significant factor in the eastern Pioneer Mountains was glaciation: none of the valleys that contain significant placers was glaciated. Most of the valleys in the eastern Pioneer area, on the other hand, have been deeply scoured by valley glaciers-at least the upper stretches of these valleys that are within the area. The 10,000 years, more or less, since the glaciers melted have probably been insufficient to reestablish placer deposits in the glaciated portions of the streams. The portions of the valleys below glacier termini would be more likely sites for the preservation of placers. 




Figure 13. Mineral potential map-skarn deposits of tungsten, copper, and iron; phosphate deposits; and manganese deposits. Areas of low potential for skarn deposits shown by solid line. Outcrop of Phosphoria Formation, which contains phosphate resources, shown by dashed line. Outcrop of Dinwoody Formation, which contains manganese occurrences outside area, shown by dotted line. 
Tertiary sedimentary deposits in the northwest and southwest parts of the area have some placer potential, perhaps, but little is known of the specific source of gravels in those deposits or the drainage network that produced them. Furthermore, these deposits are mostly very poorly sorted, which suggests that they were deposited in an environment that was not conducive to concentration of detrital gold, and no associated lode source is known. On the other hand, these deposits are poorly exposed so that parts of them could contain favorable stream gravels. On this basis, these Tertiary deposits are given a low potential for placer gold deposits.

Unglaciated stream valleys that contain a lode source are very rare in the eastern Pioneer area. Price Creek and St. Louis Creek drain the Elkhorn mining district which contained a little lode gold. Billings Creek was glaciated upstream from the Polaris mine, but, from the mine downstream, the small amount of stream gravel present has low potential. Several other streams in the southwestern part of the area have potential lode sources in the Polaris and Baldy Mountain mining districts and have a low possibility of containing placers: Farlin, Steel, Driscoll, Scudder Creeks, and both forks of Dyce Creek are considered to have low potential for placer gold.

\section{Phosphate}

The Melrose phosphate district (fig. 13) encompasses over $800 \mathrm{~km}^{2}$ on the northeast flank of the Pioneer Mountains and adjacent areas to the northwest and northeast. The district is considered by Swanson (1970) to include a small area in the northeastern part of the eastern Pioneer area. The Dillon phosphate district joins the Melrose district on the south but is entirely east of the eastern Pioneer area and is not discussed further. Phosphate rock has been mined from several mines in the Melrose district near the mouth of Canyon Creek. These mines have not been active for several years.

The phosphatic sedimentary rocks in southwest Montana are in the Phosphoria Formation of Permian age. Of the two members of the Phosphoria that are particularly valuable for phosphate (the Retort and Meade Peak Phosphatic Shale Members), the Retort Member is evidently the only one present-at least thick enough to be of economic importance-in the Melrose district. On the northeast flank of the Pioneer Mountains, the Paleozoic rocks, including the Phosphoria, are in a series of northwest-trending folds that are commonly overturned to the northeast and variably faulted. The Phosphoria is preserved mainly in synclines. One of these, the Trapper Creek syncline (Swanson, 1970), is partly within the eastern Pioneer area and the Phosphoria is in faulted segments in its nose and flanks on the ridge between Trapper and Canyon Creeks. A prospect trench about $200 \mathrm{~m}$ northeast of the top of Cleve Mountain exposes oolitic phosphate rock and phosphatic shale. The iron-phosphate minerals strengite and metastrengite are present at this locality.

Swanson (1970) estimates that the Phosphoria in the Trapper Creek syncline has $2 \mathrm{~m}$ of phosphatic shale that contains more than 18 percent $\mathrm{P}_{2} \mathrm{O}_{5}$. Such rocks are considered to be low-grade phosphate resources that are submarginal at this time. In addition to thinness and low grade, small-scale folding, faulting, and shearing produce unfavorable mining conditions. The iron-phosphate minerals, if abundant, could also be detrimental to processing.

\section{Stratabound Copper}

Evidence for stratabound copper in rocks of the Belt Supergroup has not been found except for a single occurrence possibly of this type at Big Point on the west edge of the study area. The rocks at Big Point are medium- to light-gray, thin- to medium-bedded, finegrained silty quartzite; dark-gray silty argillite forms laminae and mud chips on bedding planes and mud chips in quartzite. Mud cracks and ripple marks are common. These beds are assigned tentatively to the Mount Shields Formation, perhaps the upper part.

Green secondary copper minerals coating joints and bedding planes were found in a stratigraphic zone about $1 \mathrm{~m}$ thick that contains light-green argillite beds and carbonate beds in addition to quartzite. No sulfide minerals or any evidence of epigenetic mineralization is in evidence. A sample of copper-stained quartzite contained $500 \mathrm{ppm}$ copper but no detectable silver or other elements in anomalous amounts that might suggest the nature of the deposit.

Although this occurrence may be of the "Beltcopper" type, as described by Harrison (1972), its apparently small size and the lack of other similar occurrences suggest that the eastern Pioneer area has low potential for deposits of this type.

\section{Manganese}

A regolith at the top of the Dinwoody Formation has been prospected for manganese in the Trapper Creek area northeast of the eastern Pioneer area (fig. 13). According to local residents, the prospecting was done during World War II. No records of production are known. The eastern Pioneer area has low potential for manganese resources in the Dinwoody Formation.

\section{CONCLUSIONS}

The eastern Pioneer area is in a highly mineralized region that contains numerous mining districts, where mining has been under way since 1862. Many of the factors responsible for localizing the various types of ore 
mined in these districts are sufficiently well developed within the eastern Pioneer area to indicate that the entire area has some-albeit very low in some partspotential for one or another type of mineral deposit. By comparing the geological, geochemical, and geophysical characteristics of nearby mining districts with the study area, certain tracts can be assigned specific levels (high, moderate, low) of mineral potential for one or more deposit types (fig. 14). The types known to be present or considered most likely to be found on the basis of the known geological environment are: (1) vein and replacement deposits of base and precious metals, (2) stockwork molybdenum, (3) skarn deposits of tungsten, copper, or iron, and (4) phosphate. Other deposit types for which some evidence is available for their presence but for which no areas of specific potential could be identified are placer gold, stratabound copper, and sedimentary manganese.

\section{REFERENCES}

Arth, J. G., Zen, E-an, Sellers, George, and Hammarstrom, Jane, 1986, High initial $\mathrm{Sr}$ isotopic ratios and evidence for magma mixing in the Pioneer batholith of southwest Montana: Journal of Geology, v. 94, p. 410-430.

Berger, B. R., Van der Voort, J. L., Siems, D. F., and Welsch, E. P., 1979, Geochemical exploration studies in the Dillon, Montana-Idaho $1^{\circ} \times 2^{\circ}$ quadrangle: Geochemical reconnaissance of mining districts in the southern Pioneer Mountains and vicinity, Beaverhead County, Montana: U.S. Geological Survey Open-File Report 79-1426, 45 p.

Berger, B. R., Breit, G. N., Siems, D. F., Welsch, E. P., and Speckman, W. S., 1979, A geochemical survey of mineral deposits and stream deposits in the Eastern Pioneer wilderness study area, Beaverhead County, Montana: U.S. Geological Survey Open-File Report 79-1079, 128 p.

Calbeck, J. M., 1975, Geology of the central Wise River valley, Pioneer Mountains, Beaverhead County, Montana: Missoula, University of Montana, M. S. thesis, 89 p.

Defense Mapping Agency Aerospace Center, 1974, World relative gravity reference network, North America, part 2: DMAAC Ref. Pub. No. 25, with supplement updating gravity values to the International Gravity Standardization Net $1971,1635 \mathrm{p}$.

Elliott, J. E., 1982, Model for contact metasomatic tungsten/copper/gold deposits, in Characteristics of mineral deposit occurrences, R. L. Erickson, compiler: U.S. Geological Survey Open-File Report 82-795, p. 49-54.

Fraser, G. D., and Waldrop, H. A., 1972, Geologic map of the Wise River quadrangle, Silver Bow and Beaverhead Counties, Montana: U.S. Geological Survey Geologic Quadrangle Map GQ-988, scale 1:24,000.

Geach, R. D., 1972, Mines and mineral deposits, Beaverhead County, Montana: Montana Bureau of Mines and Geology Bulletin 85, 194 p.

Goudarzi, H., 1941, Geology and ore deposits of the Quartz Hill mining area, Beaverhead County, Montana: Butte, Montana College of Mineral Science and Technology, M.S. thesis, $52 \mathrm{p}$.
Hammitt, R. W., and Schmidt, E. A., 1982, Geology and mineralization of the Cannivan Gulch deposit, Beaverhead County, Montana, p. 15-20, a section in Roadlog for field trip in eastern Pioneer Mountains, Montana, by R. C. Pearson: Guidebook of the Seventh Annual Tobacco Root Geological Society Field Conference, 87 p.

Harrison, J. E., 1972, Precambrian Belt basin in northwestern United States-Its geometry, sedimentation, and copper occurrences: Geological Society of America Bulletin, v. 85, p. $1215-1240$.

Karlstrom, T. N. V., 1948, Geology and ore deposits of the Hecla mining district, Beaverhead County, Montana: Montana Bureau of Mines and Geology Memoir 25, $87 \mathrm{p}$.

Kirkemo, Harold, Anderson, C. A., and Creasey, S. C., 1965, Investigations of molybdenum deposits in the conterminous United States, 1942-60: U.S. Geological Survey Bulletin 1182-E, $90 \mathrm{p}$.

Klepper, M. R., Robinson, G. D., and Smedes, H. W., 1974, Nature of the Boulder batholith of Montana-Discussion: Geological Society of America Bulletin, v. 85, no. 12, p. 1953-1958.

Moore, G. T., 1956, The geology of the Mt. Fleecer area, Montana: Bloomington, University of Indiana, Ph.D. thesis, $88 \mathrm{p}$.

Myers, W. B., 1952, Geology and mineral deposits of the northwest quarter Willis quadrangle and adjacent Browns Lake area, Beaverhead County, Montana: U.S. Geological Survey Open-File Report 52-105, 46 p.

Pattee, E. C., 1960, Tungsten resources of Montana-Deposits of the Mount Torry batholith, Beaverhead County: U.S. Bureau of Mines Report of Investigations 5552, 41 p.

Pearson, R. C., and Berger, B. R., 1980, Geology and geochemistry of some hydrothermally altered rocks, Pioneer Mountains, Beaverhead County, Montana: U.S. Geological Survey Open-File Report 80-706, 24 p.

Pearson, R. C., and Zen, E-an, 1985, Geologic map of the eastern Pioneer Mountains, Beaverhead County, Montana: U.S. Geological Survey MF Map 1806-A.

Richards, R. W., and Pardee, J. T., 1925, The Melrose phosphate field, Montana: U.S. Geological Survey Bulletin 780-A, $32 \mathrm{p}$.

Ruppel, E. T., O'Neill, J. M., and Lopez, David, 1983, Geologic map of Dillon $1^{\circ} \times 2^{\circ}$ quadrangle, Montana: U.S. Geological Survey Open-File Report 83-168.

Schmidt, E. A, and Worthington, J. E., 1979, Geology and mineralization of the Cannivan Gulch molybdenum deposit, Beaverhead County, Montana [abs.]: Program of the 1977 Annual Meetings of the Geological Association of Canada, Mineralogical Association of Canada, Society of Economic Geologists, and Canadian Geophysical Union held in Vancouver, British Columbia.

Shenon, P. J., 1931, Geology and ore deposits of Bannack and Argenta, Montana: Montana Bureau of Mines and Geology Bulletin 6, $77 \mathrm{p}$.

Smith, J. L., 1970, Petrology, mineralogy, and chemistry of the Tobacco Root batholith, Madison County, Montana: Bloomington, Indiana University Ph.D. thesis, 164 p.

Snee, L. W., 1978, Petrography, K-Ar ages, and field relations of the igneous rocks of the Pioneer batholith, southwestern Montana: Columbus, Ohio State University, M.S. thesis, $110 \mathrm{p}$. 


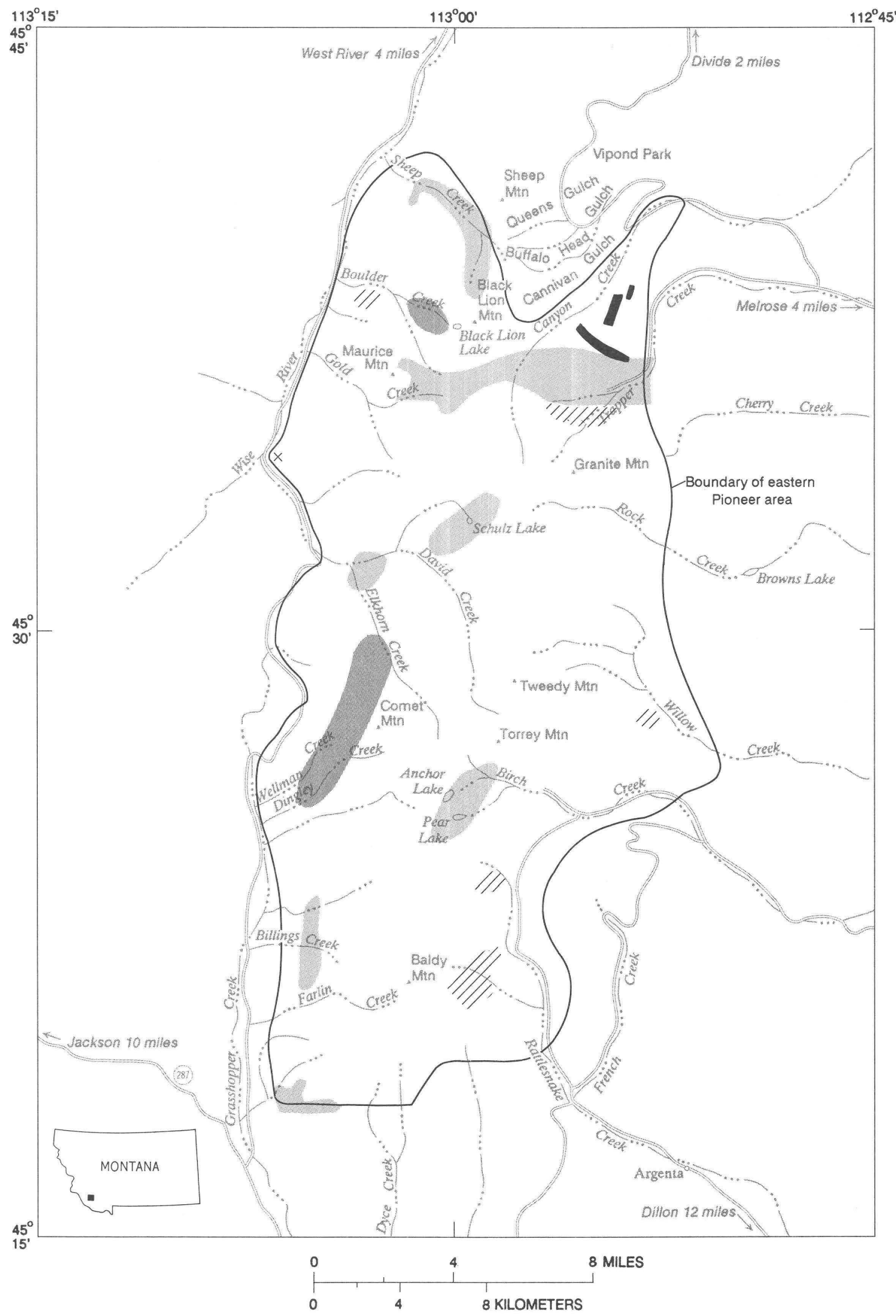

Figure 14. Summary of mineral resource potential, eastern Pioneer area. Dark shading, high potential; light shading, moderate potential; line pattern, low potential; solid line, area containing phosphate resources; $\mathrm{x}$, occurrence of stratabound copper. 
1982, Emplacement and cooling of the Pioneer batholith, southwestern Montana: Columbus, Ohio State University, Ph.D. thesis, 320 p.

Streckeisen, Albert, 1976, To each plutonic rock its proper name: Earth Science Reviews, v. 12, p. 1-33.

Swanson, R. W., 1970, Mineral resources in Permian rocks of southwest Montana: U.S. Geological Survey Professional Paper 313-E, p. 661-777.

Taylor, A. V., 1942, Quartz Hill district near Divide, Montana, in Newhouse, W. H., ed., Ore deposits as related to structural features: Princeton University Press, p. 215-216.

U.S. Geological Survey, 1979, Aeromagnetic survey of West Pioneer-Beaverhead, Montana: U.S. Geological Survey Open-File Report 79-758.
Willis, G. F., 1978, Geology of the Birch Creek molybdenum prospect, Beaverhead County, Montana: Missoula, University of Montana, M.S. thesis, 74 p.

Winchell, A. N., 1914, Mining districts of the Dillon quadrangle, Montana, and adjacent areas: U.S. Geological Survey Bulletin 575, $191 \mathrm{p}$.

Zen, E-an, 1977, Some regional tectonic problems inferred from the Pioneer Mountains, Montana: Geological Society of America Abstracts with Programs, v. 9, no. 6, p. 779-780.

Zen, E-an, and Dutro, J. T., Jr., 1975, Upper PrecambrianLower Cambrian(?) sedimentary sequence, Pioneer Mountains, southwest Montana: Geological Society of America Abstracts with Programs, v. 7, no. 7, p. 1327. 



